\title{
Vegetation Map Accuracy Assessment: Fort Benning, Georgia
}

\author{
J. Watts, W.R. Whitworth, A. Hill, G.I. Wakefield, T. Davo, and L.J. O'Neil
}

In 1993 the U.S. Army Construction Engineering Research Laboratory (CERL) became involved in the United States Geological Survey, Division of Biological Resources/National Park Service (USGS/NPS) National Vegetation Mapping Program by serving as an interagency peer reviewer. This initial involvement led to discussions on vegetation mapping alternatives for military lands and a completed vegetation map for Fort Benning, GA. To validate the vegetation map and help managers realize its potential use as a natural resources and military training management tool, an accuracy assessment was conducted.

Armed with a field key to the plant communities on the Fort Benning map and a project sampling design, intensive fieldwork was conducted to collect the data required to assess the vegetation map's accuracy. Field data was analyzed and an error analysis of the map was completed. This report includes lessons learned and recommendations for future vegetation mapping and accuracy assessment projects. 


\section{Foreword}

This study was conducted for the Environmental Management Division, Directorate of Public Works, Fort Benning, Georgia, under Military Interdepartmental Purchase Request (MIPR) No. MIPR8CDPW10029; Work Unit N N8, "Accuracy Assessment for Fort Benning Georgia." The technical monitor was Theresa Davo, (ATSH-OTR) LCTA Coordinator at Fort Benning.

The work was performed by the Ecological Processes Branch (CN-N) of the Installations Division (CN), Construction Engineering Research Laboratory (CERL). The initial CERL Principal Investigator was Dr. Alison Hill, now with the U.S. Forest Service. Under her leadership, the project was developed, tasks defined, the multidisciplinary team assembled, and fieldwork completed. She assisted in the preliminary fieldwork and provided valuable comments on the final report. The current Principal Investigator is William Whitworth. J oe Watts and Gerald Wakefield are Principle Investigators at the U.S. Army Topographic Engineering Center (TEC), and L. J ean O'Neil is a Principal Investigator at the U.S. Army Waterways Experiment Station (WES).

Fieldwork was critical to the success of the project, and was largely provided by Verl Emrick and Eric Schreiber of CERL. Additionally, Dennis Gravatt of WES and William Whitworth provided significant assistance collecting the plot data in the field. Finally, thanks to the Range Control Branch at Fort Benning for their professionalism, helpfulness, and accommodation of our presence on the training areas.

Dr. Harold E. Balbach is Branch Chief, CECER-CN-N, and Dr. J ohn T. Bandy is Division Chief, CECER-CN. The technical editor was Gloria J . Wienke, Information Technology Laboratory.

The Director of CERL is Dr. Michael J . O'Connor. 


\section{Contents}

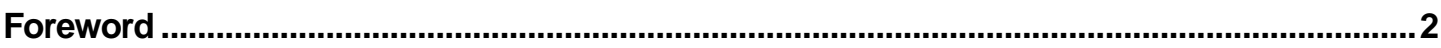

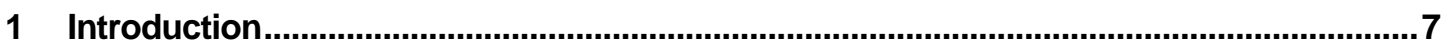

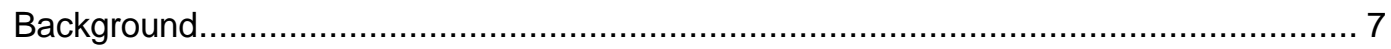

Objective

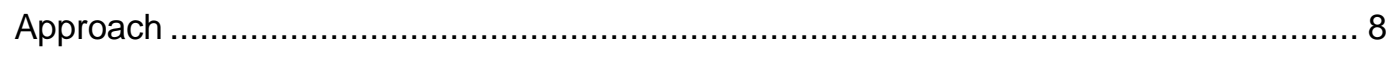

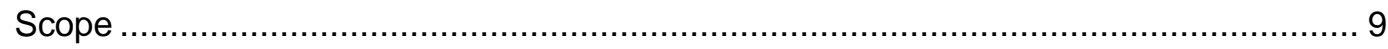

Mode of Technology Transfer ....................................................................... 9

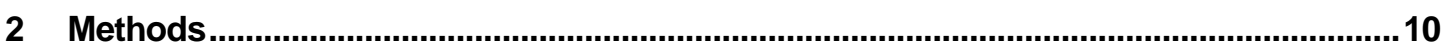

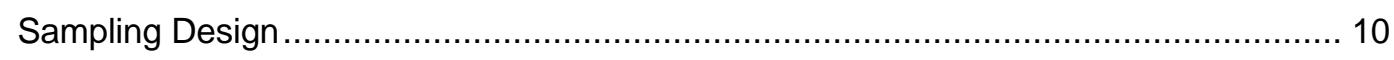

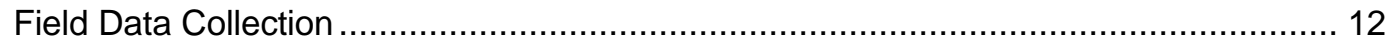

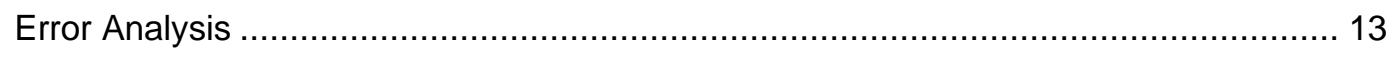

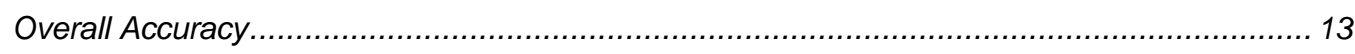

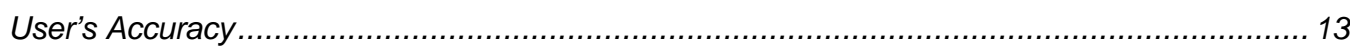

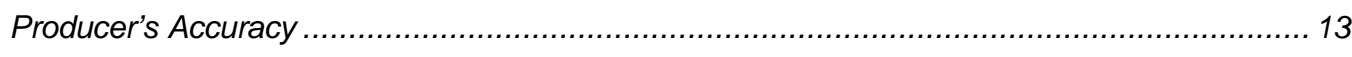

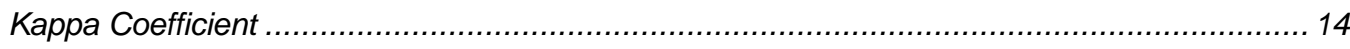

3 Results........................................................................................................16

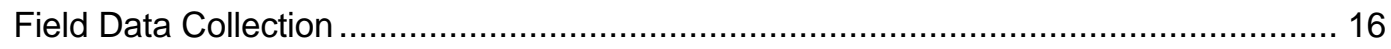

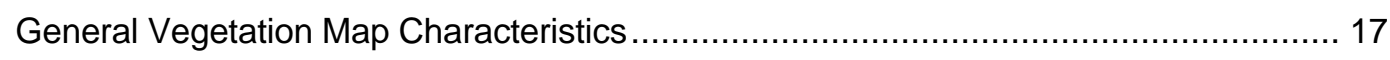

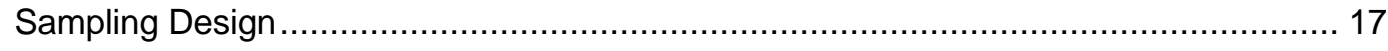

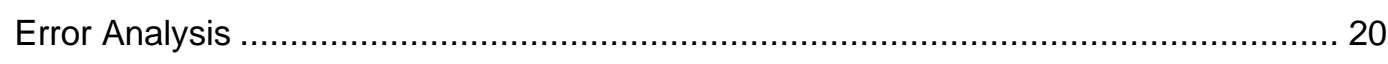

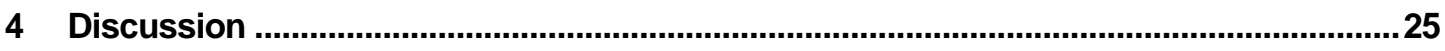

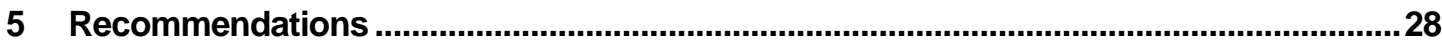

Literature Cited ...............................................................................................................31

Appendix A: Common Names for the Woody Plant Species Found in the Field Key..........33

Appendix B： Alliance ID and Name

Appendix C: ARC/NFO Macro Language Programs .........................................................37

Appendix D: Field Notes .........................................................................................5 


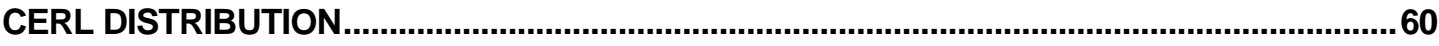

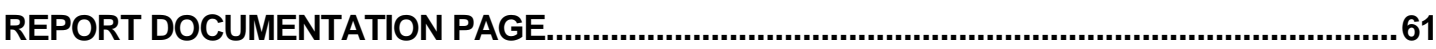




\section{List of Figures and Tables}

\section{Figures}

1 Comparison of theoretical versus actual sampling ............................................. 19

\section{Tables}

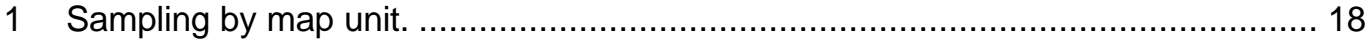

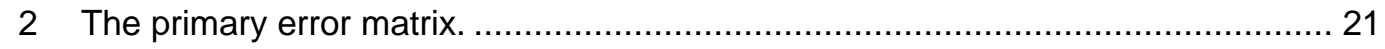

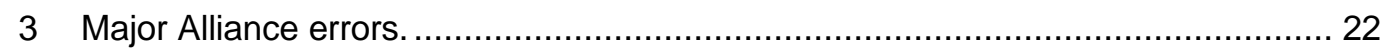

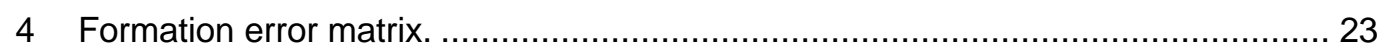

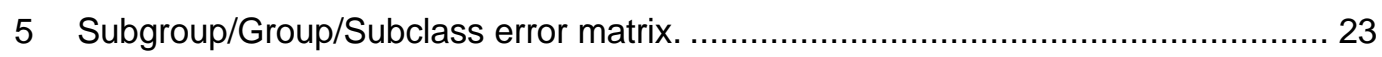

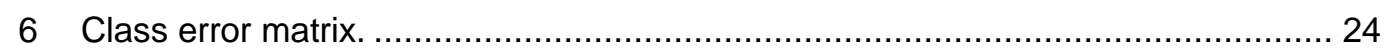

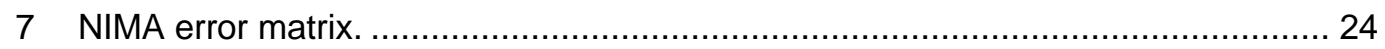

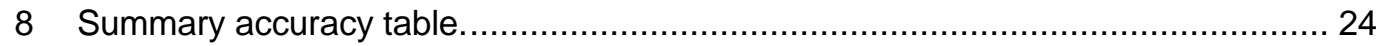





\section{Introduction}

\section{Background}

In 1993 the U.S. Army Construction Engineering Research Laboratory (CERL) became involved in the National Biological Survey/National Park Service (NBS/NPS) National Vegetation Mapping Program by serving as an interagency peer reviewer. (Due to reorganization, the program is now sponsored by the U.S. Geological Survey/National Park Service [USGS/NPS].) This initial involvement led to discussions on vegetation mapping alternatives for military lands and the identification of partnering opportunities. One such opportunity was initiated at Fort Benning, GA, in 1994 and enabled CERL to test the USGS/NPS vegetation mapping procedures in the context of a military setting. The resulting map, completed in 1996, was the first known Army effort to map vegetation in strict accordance to the Federal Geographic Data Committee (FGDC) standards and methodology, and was at the floristic alliance level. Funding to perform an accuracy assessment of the map was not available until 1998. This research project involves conducting the accuracy assessment.

Fort Benning is the home of the U.S. Army Infantry Training Center. Its 73,653 ha $(182,000$ acres) of land contain important habitat for over 90 threatened, endangered, and special concern plant and animal species. To validate the Fort Benning vegetation map and realize its potential use as a natural resources and military training management tool, an accuracy assessment (AA) is critical (The Nature Conservancy [TNC] and Environmental Systems Research Institute [ESRI], Draft, 1994b). This AA should help installation personnel determine how much confidence they should assign to the data and the resulting products, and will allow them to better understand its appropriateness for various applications. These determinations are especially important for compliance with various environmental regulations, such as Army Regulation (AR) 200-3 (Headquarters, Department of the Army 1995), Department of Defense Instruction 4715.3 (3 May 1996), the Sikes Act (16USC), the Deputy Chief of Staff for Operations' (DCSOPS) Integrated Training Area Management (ITAM) program strategy (AR 350-4, 8 May 1998 and HQDA 17 August 1995), the Assistant Chief of Staff for Installation Management's (ACSIM) Army Goals and I mplementing Guidance for Natural Resources Planning Level Surveys (PLS), and installation Integrated Natural Resource Management Plan (INRMP)(DA Memo 21 March 
1977). These regulations and guidance, among other items, require Army installations to map and monitor vegetation.

\section{Objective}

The objective of this effort is to assess the accuracy of an alliance-level vegetation map previously developed for Fort Benning, GA.

\section{Approach}

This project consisted of four relatively discrete phases. First, under a separate work unit, a field key to the plant communities comprising the Fort Benning map was developed by The Nature Conservancy (TNC). Appendix A contains a list of the woody plant species included in the key. Funding for this effort was obtained through the Army's Conservation Assistance Program (CAP). The TNC general classification scheme was based on published information (TNC and Environmental Systems Research Institute [ESRI] Draft, November 1994a), and, other than LCTA data, little was known about the diversity of communities found on Fort Benning. Second, the U.S. Army Topographic Engineering Center (TEC) generated a project sampling design in accordance with the sampling criteria used by the USGS/NPS in the National Vegetation Mapping Program. After discussions between CERL and TEC, the Fort Benning alliances were re duced from 83 to 51 (crosswalking) in an effort to be consistent with revisions in TNC's vegetation classification system for the southeastern United States. GeoMarine, Inc., Plano, TX, created the original vegetation map and was tasked to do the crosswalk. The alliance names and their associated map numbers are found in Appendix B. Third, intensive fieldwork, using the TNC-developed field key, was conducted at Fort Benning in order to collect the data required to assess the vegetation map's accuracy (TNC and ESRI, Draft 1994b). The fieldwork was conducted by CERL and the U.S. Army Waterways Experiment Station (WES). Fourth, TEC also performed and interpreted an error analysis of the Fort Benning vegetation map based on the collected field data. Finally, the data, results, and other input from CERL, TEC, and WES were integrated into this report.

The overall objective of assessing the alliance-level accuracy of the Fort Benning vegetation map can be divided into the following questions:

1. What are the general characteristics of the vegetation map in terms of minimum mapping unit, number of polygons per dass, and thematic accuracy? 
2. How do the collected samples relate to the theoretical sample design, and do the differences between theactual and theoretical samples affect the error analysis?

3. What arethe overall accuracy statistics of thealliance vegetation map?

4. Which alliances aremapped well and which aremapped poorly?

5. How does thematic map accuracy vary as map units are collapsed in accordance with The Nature Conservancy Vegetation Classification System for the Southeastern United States hierarchy and recoded in the National I magery and Mapping Agency's vegetation dassification system?

6. What is theapproximate spatial accuracy of thealliance map?

Answers to these questions can be found in Chapter 3, Results. Chapter 4, Discussion, focuses on the question: What are some error sources and recommendations for future mapping projects?

\section{Scope}

Findings contained within this report are most useful to the Fort Benning natural resource managers, although other installations considering a similar accuracy assessment project may find this document equally informative. Information on the international classification of ecological communities and the terrestrial vegetation of the southeastern United States can be obtained by writing The Nature Conservancy, Southeast Regional Office, P.O. Box 2267, Chapel Hill, North Carolina, 27515-2267.

\section{Mode of Technology Transfer}

This report, and the supporting data will be provided to F ort Benning staff. 


\section{Methods}

The following section details the project sampling design, including the techniques used to automate the sample allocation process. It explains the field sampling protocols related to navigation, sample elimination, field key use, and data recording procedures, and describes the error analysis terms and procedures used (TNC and ESRI, Draft 1994a,b).

\section{Sampling Design}

The two main steps in generating a sample design are determining the per class sample sizes and spatial allocation of samples. The primary determinants of per class sample size for this project were the criteria used in the National Vegetation Mapping Program. Those criteria are based on the establishment of maximum (30) and minimum (5) per class sample sizes. Five sample size categories were used:

1. Abundant dasses:

- total acreage $>50$ hectares

- number of polygons $\geq 30$

- sample size $=30$

2. Relatively abundant dasses:

- total acreage $>50$ hectares

- number of polygons $<30$

- $\quad$ sample size $=20$

3. Relatively rare classes:

- total acreage $<50$ hectares

- number of polygons $\geq 30$

- sample size $=20$

4. Rare classes:

- total acreage $<50$ hectares

- number of polygons $>5$ but $<30$

- sample size $=5$ 
5. Very rare dasses:

- total acreage $<50$ hectares

- number of polygons $<5$

- $\quad$ sample size $=1$ per polygon

The next step in the sample design was sample placement. Our approach was a stratified, random sampling design. In an attempt to ensure representation of all vegetation alliances in the error assessment, alliances portrayed on the subject vegetation map (Geo-Marine 1997a and b) were used as strata. The word "strata" in this context simply means independent sampling units (i.e., placement of samples within one vegetation type [strata] does not affect sample placement in other vegetation types). Recognizing that scientific rigor and crew safety are both important, vegetation ecotones, reforested areas, dud areas, and exclusion areas were avoided as potential sample locations. The avoidance areas (environmental constraints) came from geographic information system (GIS) layers provided by Fort Benning personnel.

Given the large number of polygons for some vegetation types, it was neither feasible nor necessary to sample every polygon. Within each alliance type, polygons outside of avoidance areas were randomly selected. In the selected polygons, point locations in the Universal Transverse Mercator (UTM) coordinate system on the World Geodetic System-1984 datum were randomly selected. Any random point falling within 30 meters of a vegetation boundary portrayed on the subject vegetation map was eliminated. This decision recognizes: (1) the interpretive nature of vegetation mapping and the realization that sharp demarcation lines between vegetation types are rare in nature, (2) the difficulty in assigning vegetation alliances in ecotonal areas, and (3) the confusion of spatial error for thematic error when polygon boundaries are strictly adhered to. We also realize that field time could be optimized by establishing buffers of 500 meters from the road network portrayed on the installation GIS road layer. All random points outside of the road buffers were eliminated. These sample placement criteria are embodied in several ARC/INFO* Macro Language programs, which were used to develop the project sample list (Appendix C).

In addition to thematic accuracy assessment, the spatial accuracy of the Fort Benning vegetation maps was also evaluated in this project. Efforts in this area

\footnotetext{
* ARC/INFO is a product of Environmental Systems Research Institute, Inc., 380 New York Street, Redlands, CA 92373-8100. Citing product names does not constitute endorsement by the U.S. Army or the Federal government.
} 
were limited since the subject vegetation map does not contain a large number of well-defined (topographic) features required to perform a robust spatial accuracy assessment. All features assessed were road intersections shown on both the vegetation map and the Fort Benning road coverage that served as the reference data source. Note that road intersections are depicted on the vegetation map as intersections of "maintained grass" and "bare ground" polygons rather than as road line features.

\section{Field Data Collection}

The fieldwork portion of this study required researchers to navigate, via a global positioning system (GPS), to a number of random survey points. Field data collection occurred between 22 J une 1998 and 12 J uly 1998. Crews normally consisted of two people, but occasionally only one person surveyed. The survey plot allocation procedure followed a stratified random design weighted by the area that each vegetation class covered on the installation. A total of 1255 locations were identified as potential survey points, with the actual number of visited sites being determined by manpower availability and time. Survey points represented each of the 51 alliance-level vegetation classes thought to occur (TNC 1998) on the installation.

Prior to the start of installation-wide independent data collection, individual field crew members practiced using the plant community field key on the same plot locations. This was an effort to promote quality control through consistency in key interpretation and species identification.

Each day, adequately trained field crews were given an assignment list of GPS point coordinates with plot locations. The crews were not provided the vegetation class associated with each point (coordinates) to prevent bias. Using handheld Rockwell Precision Lightweight GPS Receiver (PLGR) units and other land navigation aids (e.g., compass and topography maps), observers navigated to the plot locations. In navigating to a point, a PLGR accuracy reading of plus or minus 20 meters or less was deemed acceptable for the purposes of this study. The actual accuracy reading was recorded on each plot form. It was anticipated that in some instances observers would not be able to reach a point due to a barrier (swamp/stream, impassible road, or persistent military activity). If the original point was within 50 meters of the field crew's forward-most position, a new point would be randomly selected and the GPS location recorded. If the barrier was greater than 50 meters to the original point, the point was omitted from the day's schedule and the observers moved on to the next point. 
Once at a point, the crew used the key to the plant community alliances provided by The Nature Conservancy (1998). The extent of the area used to identify the community is equal to the original minimum mapping unit (MMU) of 0.8 ha (2 acres). That is, this MMU indicates that all plant community key-related observations are made within 50 meters surrounding the GPS point. Based on woody species present and relative dominance, the crew recorded a primary alliance for the point. A secondary alliance was recorded when there were two possible designations based on the criteria and/or alliance characteristics given within the field key. On those occasions where a secondary alliance was recorded, the degree of confidence was recorded for each designation (high, medium, or low). In addition, field notes were recorded about the site, including tree and shrub stratum species present, percent vegetative cover, and other incidental notes useful in determining the appropriate class (Appendix D).

\section{Error Analysis}

The thematic error analysis methods used for this project were standard techniques widely used in map accuracy assessment. The primary data representation form used was an error matrix, which is a cross tabulation of field-derived (rows) and map-derived (columns) vegetation type assignments at individual field sample locations. Four key metrics derived from error matrices are defined below:

Overall Accuracy

- Definition: The percentage of correctly mapped samples.

- Computation: The sum of the main diagonal elements of the error matrix divided by the total number of samples.

\section{User's Accuracy}

- Definition: The percentage of map-derived samples that are correctly mapped.

- Computation:

- Individual map units: dividend of the main diagonal element and the corresponding column total.

- Overall: Average of individual user's accuracies.

\section{Producer's Accuracy}

- Definition: The percentage of field-derived samples that are correctly mapped. 
- Computation:

- Individual vegetation types: dividend of the main diagonal element and the corresponding row total.

- Overall: Average of individual producer's accuracies.

\section{Kappa Coefficient}

- Definition: A measure of the difference between the observed agreement between the reference data and the subject map and the chance agreement between those two items.

- Computation: $\mathrm{Kappa}=\left(\mathrm{P}_{\text {correct }}-\mathrm{P}_{\text {chance }}\right) /\left(1-\mathrm{P}_{\text {chance }}\right)$

where:

$\mathrm{P}_{\text {correct }}=$ proportion of correctly mapped entries

$\mathrm{P}_{\text {chance }}=$ proportion of samples that could be expected to be correctly mapped by chance

Using the hierarchical nature of the TNC Vegetation Classification System used in this project, the above metrics were computed at the alliance, formation, subgroup/group/subclass, and class levels. The subgroup, group, and subclass levels were combined because the Fort Benning vegetation map has the same number of map units (nine) for all three levels. The above metrics were computed after recoding the alliance types into the National Imagery and Mapping Agency's vegetation classification system (brushland, grassland, deciduous forest, evergreen forest, and mixed forest). Translation of vegetation type labels from the TNC scheme was performed to assess the impacts that choice of classification system has on map accuracy assessment.

The spatial accuracy of the subject vegetation map was assessed using the widely accepted root mean square error (RMSE) formula as implemented in the ERDAS I magine* software package. The RMSE is calculated as follows:

RMSE $=\sqrt{ }\left[\left(\mathrm{E}_{\text {map }}-\mathrm{E}_{\text {road }}\right)^{2}+\left(\mathrm{N}_{\text {map }}-\mathrm{N}_{\text {road }}\right)^{2}\right]$

where:

$\mathrm{E}_{\text {map }}$ and $\mathrm{N}_{\text {map }}$ are sample UTM coordinates derived from the subject vegetation map

$\mathrm{E}_{\text {road }}$ and $\mathrm{N}_{\text {road }}$ are sample UTM coordinates derived from the Fort road coverage

\footnotetext{
* Imagine is a product of ERDAS, Inc., 2801 Buford Highway, NE, Atlanta, GA 30329-2137. Citing product names does not constitute endorsement by the U.S. Army or the Federal government.
} 
The following chapter addresses the research questions posed in the Approach section. Numeric results and associated interpretations of the error analysis are presented. 


\section{Results}

This chapter briefly describes the field data collection effort and the theoretical and actual sampling designs of the project. It addresses the overall characteristics of the Fort Benning vegetation map, and provides relevant tables and graphs quantifying the map's accuracy. Answers to the project questions posed in the Approach section of this document are provided.

\section{Field Data Collection}

Each day crews visited plots with the intent of maximizing productivity. Specifically, areas of military activity were avoided and plots were grouped when possible to allow visits to multiple plots from a single departure point. A total of 1255 potential points were identified prior to the start of field work. Field crews were only able to visit and make alliance-level determinations on 750 of these points (60 percent). Often, crews were not able to visit a site because of the difficulty in finding a "passable" road/trail; fallen trees made many documented roads/trails impassible. Additionally, some of the passible roads/trails could not be accessed due to training activity in an adjacent training area. More problematic, however, was the consistently high temperature (95 to $105^{\circ} \mathrm{F}$ [ 35 to $40{ }^{\circ} \mathrm{C}$ ]) and relative humidity experienced through the field effort. The weather conditions, and the time to safely navigate (by vehicle then on foot) to the more isolated points, increased the survey time. The researchers collecting data during the field period averaged 11.5 days per researcher, with an estimated total of 500 man-hours of labor. Or, in other terms, we estimate the field effort at 0.67 man-hours expended per site visited. Daily field time was calculated as the time field crews left the Fort Benning quarters in the morning to just after the last plot was visited in the evening. Also included were incidental events such as trips to pick up equipment, eat lunch, and check in with Fort Benning range control and/or natural resource personnel. While not data collection per se, they represent essential tasks associated with field work that need to be recognized and allowed for. 


\section{General Vegetation Map Characteristics}

What are the general characteristics of the vegetation map in terms of minimum mapping unit, number of polygons per class, and thematic accuracy?

The Fort Benning vegetation map is a single ARC/INFO polygon coverage with seven attributes: area, perimeter, software-assigned identification number, user assigned identification number, vegetation alliance name, vegetation alliance numeric code, and a symbol code. A total of 51 vegetation alliances delineated on the map represented a total of 6,490 polygons. At the other National Vegetation Classification System (NVCS) levels, there are 15 formations, 9 subgroups, 9 groups, 9 subclasses, and 4 classes. The median number of polygons per alliance is 65 (mean $=127$ ) ranging from a minimum of 3 for the Pinus serotina Saturated Woodland Alliance and the Fraxinus pennsylvanica - (UImus americana) Celtis (occidentalis, Iaevigata) Temporarily Flooded Forest Alliance to a maximum of 582 for the Pinus taeda Forest Alliance. The distribution of polygons per class is skewed toward low polygon totals with 23 classes (45 percent) mapped using 50 or fewer polygons. The overall MMU per alliance is 0.54 ha ranging from a minimum of 0.0017 ha for the Pinus palustris - Pinus elliotii Temperate Forest Alliance to a maximum of 4.67 ha for the Pinus serotina Saturated Woodland Alliance.

\section{Sampling Design}

In this section the following questions are addressed:

How do the collected samples relate to the theoretical sample design, do the differences between the actual and theoretical samples affect the error analysis?

What are the overall accuracy statistics of the alliance vegetation map?

As previously discussed, project sample sizes per map unit were based on guidance from the National Vegetation Mapping Program. Of the 750 samples collected, 83 were not categorized into the vegetation system used on the Fort Benning vegetation map and were instead assigned to the following classes: Forestry/Recently Cut, Heavily Disturbed/Unclassifiable, Not Disturbed/Unclassifiable, Nyssa biflora - Acer rubrum - (Liriodendron tulipifera) Saturated Forest Alliance, Quercus alba - Quercus (falcata, stellata) F orest Alliance, Successional Shrubland, Pine Plantation < 5 meters in height, Ecotonal Community, and Wetland Community. That left 667 samples, or 53 percent of the target sample size, for use in the accuracy assessment. 
Table 1 shows the required per class sampling sizes, and the number and percentage of samples actually collected; Figure 1 graphically depicts undersampling by percentage class (alliance). For example, 13 alliances were undersampled by 51-75 percent of what they should have been sampled. Note that the sum effects of the sampling placement criteria chosen for this project

Table 1. Sampling by map unit.

\begin{tabular}{|c|c|c|c|}
\hline Class/Alliance & Target & Actual & Percent \\
\hline 1 & 30 & 2 & 0.07 \\
\hline 2 & 30 & 1 & 0.03 \\
\hline 3 & 31 & 28 & 0.90 \\
\hline 4 & 30 & 0 & 0.00 \\
\hline 5 & 20 & 0 & 0.00 \\
\hline 6 & 30 & 6 & 0.20 \\
\hline 7 & 20 & 3 & 0.15 \\
\hline 8 & 30 & 8 & 0.27 \\
\hline 9 & 30 & 19 & 0.63 \\
\hline 10 & 27 & 3 & 0.11 \\
\hline 11 & 30 & 1 & 0.03 \\
\hline 12 & 20 & 0 & 0.00 \\
\hline 13 & 30 & 8 & 0.27 \\
\hline 14 & 30 & 2 & 0.07 \\
\hline 15 & 3 & 7 & 2.33 \\
\hline 16 & 30 & 29 & 0.97 \\
\hline 17 & 30 & 10 & 0.33 \\
\hline 18 & 20 & 2 & 0.10 \\
\hline 19 & 30 & 20 & 0.67 \\
\hline 20 & 20 & 18 & 0.90 \\
\hline 21 & 30 & 0 & 0.00 \\
\hline 22 & 20 & 0 & 0.00 \\
\hline 23 & 30 & 8 & 0.27 \\
\hline 24 & 30 & 1 & 0.03 \\
\hline 25 & 30 & 17 & 0.57 \\
\hline 26 & 30 & 24 & 0.80 \\
\hline 27 & 30 & 18 & 0.60 \\
\hline 28 & 30 & 14 & 0.47 \\
\hline 29 & 20 & 13 & 0.65 \\
\hline 30 & 30 & 19 & 0.63 \\
\hline 31 & 20 & 15 & 0.75 \\
\hline 32 & 5 & 9 & 1.80 \\
\hline 33 & 30 & 19 & 0.63 \\
\hline 34 & 30 & 56 & 1.87 \\
\hline 35 & 20 & 35 & 1.75 \\
\hline 36 & 30 & 86 & 2.87 \\
\hline 37 & 3 & 0 & 0.00 \\
\hline 38 & 20 & 12 & 0.60 \\
\hline 39 & 30 & 25 & 0.83 \\
\hline 40 & 20 & 5 & 0.25 \\
\hline 41 & 29 & 1 & 0.03 \\
\hline 42 & 30 & 0 & 0.00 \\
\hline 43 & 5 & 0 & 0.00 \\
\hline 44 & 20 & 16 & 0.80 \\
\hline 45 & 5 & 1 & 0.20 \\
\hline 46 & 30 & 14 & 0.47 \\
\hline 47 & 30 & 55 & 1.83 \\
\hline 48 & 7 & 1 & 0.14 \\
\hline 49 & 30 & 5 & 0.17 \\
\hline 50 & 30 & 7 & 0.23 \\
\hline 51 & 30 & 24 & 0.80 \\
\hline
\end{tabular}




\section{MAP UNIT UNDERSAMPLING}

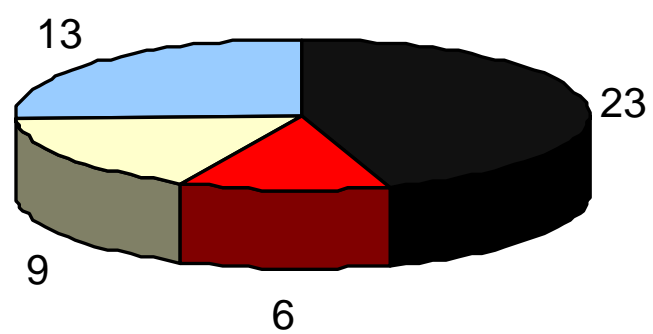

Numbers represent number of alliances in each undersampling group. $13+23+6+9=51$ alliances

Figure 1. Comparison of theoretical versus actual sampling.

(road buffers, ecotone avoidance, dud areas, etc.) eliminated the possibility of total compliance with USGS/NPS guidelines. As Table 1 and Figure 1 show, many vegetation classes were undersampled. The two primary reasons for this undersampling are: (1) discrepancies between the classification system used in the mapping and field observations and (2) map error. The required field time to survey all potential points was underestimated. This underestimation likely contributed to undersampling as well, the degree to which is difficult to assess. Field notes by the CERL field crew leader question the prevalence of several alliances, all of which were severely undersampled despite being used extensively on the vegetation map. Also, since the vegetation map polygons were used to stratify the field sampling, map units mapped with low accuracy tend to be undersampled, especially for rare vegetation types.

The impacts of undersampling on the map error analysis are moderate. For all unsampled map units ( $n=3$ ), no producer's accuracy values can be computed. Likewise, no user's accuracy values can be computed for unsampled vegetation types $(\mathrm{n}=8$ ). Only one category (Arundinaria gigantea Saturated Shrubland Alliance) fell in the overlap category. This category was neither visited in the field nor portrayed on the map at sample locations, and was therefore not induded in the computation of the Kappa Coefficient. Caution should be used, however, in interpreting per class user's and producer's accuracies for dasses sampled at low frequencies. As a general rule, results of classes falling into the abundant, relatively abundant, and relatively rare classes in which less than five field plots were taken represent minimal information.

Oversampling of certain alliances also occurred. The actual sample sizes for six dasses were substantially above that required by the sampling design, leading to 
a total of 130 extraneous plots. Much of that oversampling (56 plots) occurred in the Pinus taeda Woodland Alliance, reflecting, in part, map confusion between different pine-dominated alliances. Other than deflecting field resources away from undersampled vegetation types, oversampling does not affect the map error analysis.

\section{Error Analysis}

In this section, the remaining project questions are addressed:

Which alliances are mapped well and which are mapped poorly?

How does thematic map accuracy vary as map units are collapsed in accordance with the Nature Conservancy Vegetation Classification System for the Southeastern United States hierarchy and recoded in the National Imagery and Mapping Agency's vegetation classification system?

What is the approximate spatial accuracy of the alliance map?

What are someerror sources and recommendations for future mapping projects?

Table 2 contains the primary error matrix for this project, which represents the accuracy of vegetation alliances as mapped on the Fort Benning vegetation map. In general, the map thematic quality is poor as quantified by:

Overall Accuracy

User's Accuracy

Overall Producer's Accuracy

Kappa Coefficient
$22 \%$

$17 \%$

$26 \%$

$20 \%$

Again, User's Accuracy indicates the percentage of map-derived samples that are correctly mapped while Producer's Accuracy indicates the percentage of fieldderived samples correctly mapped. The Kappa Coefficient is a measure of the difference between the observed agreement between the reference data and the map, and the chance agreement between those two items. A Kappa value between 0.4 and 0.75 suggests a moderately accurate map. 
Table 2. The primary error matrix.

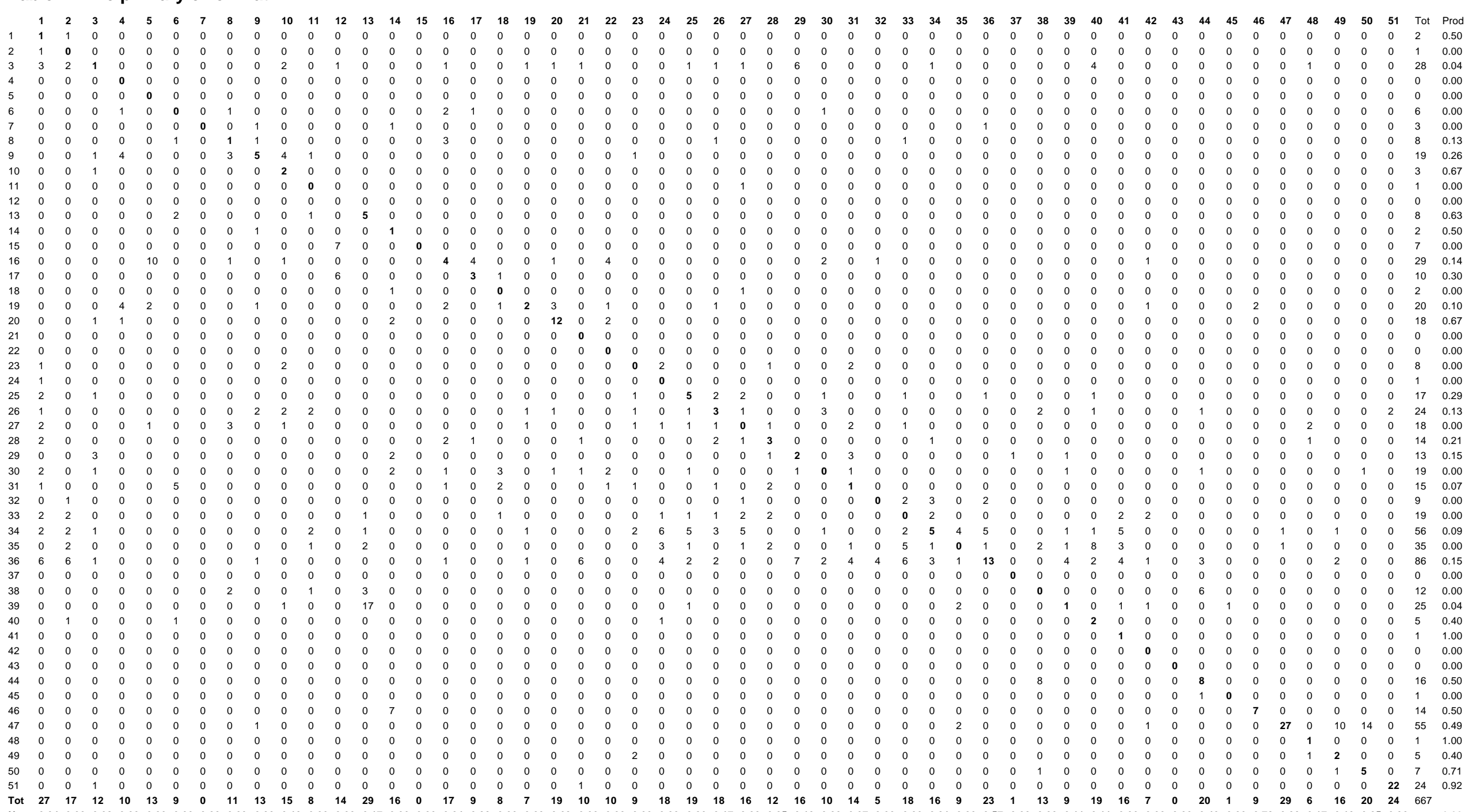

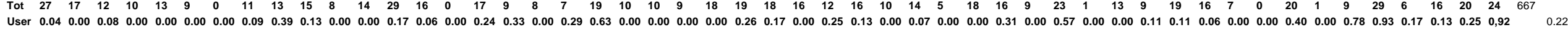

The Overall Accuracy $=22 \%$

The Kappa Index of Agreement $=0.198$.

The standard deviation of kappa $=0.006$

The $Z$ score of kappa $=32.07$. 
Table 3 lists the major errors, defined as a user's or producer's error rate of greater than or equal to 50 percent for all plots with a sample size of 10 or greater. These errors include confusions between (1) deciduous dominants (expected with leaf-off photography), woodlands, and forests of the same community; (2) natural herbaceous communities and wildlife clearings; (3) natural herbaceous communities and bare ground (probably due to scale discrepancies between photointerpretation and field work); (4) different palustrine communities (identified in field notes as difficult to discriminate); and (5) short trees and tall shrubs. However, there were serious problems in mapping evergreen-dominated forest alliances as well. For example, Pinus taeda (Ioblolly pine)-dominated forest alliances comprised 7 of 51 alliances (13.7 percent), and 189 of the 667 field samples (28.3 percent). Accuracy of these alliances ranged from 0 to just 21 percent (Table 2 ).

Tables 4, 5, and 6 present error matrices at the Formation, Subgroup/Group/ Subclass, and Class levels.

Table 7 represents the error matrix for the National Imegry and Mapping Agency (NIMA) classification system. The trend that emerges from these four tables is that the accuracy of the Fort Benning vegetation map increases slightly with decreasing information content (increasing classification level). Table 8 is a summary table of Kappa values and overall accuracies. For example, the overall

Table 3. Major Alliance errors.

\begin{tabular}{|c|c|c|}
\hline \multicolumn{3}{|c|}{ USER'S } \\
\hline FIELD CODE* & $\begin{array}{c}\text { MAP } \\
\text { CODE }^{\star \star}\end{array}$ & $\%$ OF INCORRECT SAMPLES \\
\hline 16 & 5 & 77 \\
\hline 15 & 12 & 50 \\
\hline 39 & 13 & 59 \\
\hline 36 & 21 & 60 \\
\hline 44 & 38 & 62 \\
\hline 47 & 49 & 62 \\
\hline 47 & 50 & 70 \\
\hline \multicolumn{3}{|c|}{ PRODUCER'S } \\
\hline FIELD CODE* & $\begin{array}{c}\text { MAP } \\
\text { CODE }^{\star *}\end{array}$ & $\%$ OF INCORRECT SAMPLES \\
\hline 17 & 12 & 60 \\
\hline 38 & 44 & 50 \\
\hline 39 & 13 & 68 \\
\hline 44 & 38 & 50 \\
\hline 46 & 14 & 50 \\
\hline
\end{tabular}

* The field codes/alliance IDs are listed in Appendix B. The code/ID is assigned to a plot based on the vegetation present. 
** The map codes/alliance IDs are assigned based on the vegetation map and reflect the vegetation expected to be on the plot.

Accuracy approached 60 percent when discriminating forests versus woodlands, but rapidly degraded at smaller scales such as the three P. palustris-dominated alliances (alliance numbers 33, 34, and 35). While overall accuracy at the class level may or may not be adequate when determining a training area's suitability for a particular military exercise, it clearly can present problems for natural re source personnel managing wildlife species associated with specific alliances. The endangered red-cockaded woodpecker (RCW), for example, is strongly associated with longleaf pine communities and occurs on Fort Benning. The low overall accuracy at the alliance level clearly suggests the current map has limited value as a management tool in the management of longleaf pine communities and the RCW on Fort Benning.

Table 4. Formation error matrix.

\begin{tabular}{|r|r|r|r|r|r|r|r|r|r|r|r|r|r|r|r|r|r|r|}
\hline & \multicolumn{1}{r}{} & $\mathbf{2}$ & $\mathbf{3}$ & $\mathbf{4}$ & $\mathbf{5}$ & $\mathbf{6}$ & $\mathbf{7}$ & $\mathbf{8}$ & $\mathbf{9}$ & $\mathbf{1 0}$ & $\mathbf{1 1}$ & $\mathbf{1 2}$ & $\mathbf{1 3}$ & $\mathbf{1 4}$ & $\mathbf{1 5}$ & $\mathbf{1 6}$ & Tot & Prod \\
\hline $\mathbf{1}$ & $\mathbf{9}$ & 2 & 2 & 1 & 0 & 3 & 6 & 0 & 1 & 0 & 4 & 0 & 0 & 0 & 0 & 3 & $\mathbf{3 1}$ & $\mathbf{0 . 2 9}$ \\
\hline $\mathbf{2}$ & 2 & $\mathbf{2 8}$ & 7 & 1 & 0 & 2 & 1 & 0 & 2 & 0 & 0 & 0 & 0 & 0 & 0 & 5 & $\mathbf{4 8}$ & $\mathbf{0 . 5 8}$ \\
\hline $\mathbf{3}$ & 0 & 4 & $\mathbf{1 9}$ & 4 & 0 & 2 & 2 & 0 & 1 & 0 & 0 & 0 & 0 & 2 & 0 & 36 & $\mathbf{7 0}$ & $\mathbf{0 . 2 7}$ \\
\hline $\mathbf{4}$ & 2 & 2 & 2 & $\mathbf{1 2}$ & 0 & 3 & 0 & 2 & 0 & 0 & 0 & 0 & 0 & 0 & 0 & 3 & $\mathbf{2 6}$ & $\mathbf{0 . 4 6}$ \\
\hline $\mathbf{5}$ & 0 & 0 & 0 & 0 & $\mathbf{0}$ & 0 & 0 & 0 & 0 & 0 & 0 & 0 & 0 & 0 & 0 & 0 & $\mathbf{0}$ & $\mathbf{0 . 0 0}$ \\
\hline $\mathbf{6}$ & 9 & 10 & 5 & 4 & 0 & $\mathbf{2 4}$ & 4 & 2 & 4 & 2 & 2 & 1 & 0 & 0 & 0 & 7 & $\mathbf{7 4}$ & $\mathbf{0 . 3 2}$ \\
\hline $\mathbf{7}$ & 6 & 0 & 8 & 1 & 0 & 2 & $\mathbf{3}$ & 4 & 0 & 2 & 0 & 1 & 0 & 0 & 0 & 5 & $\mathbf{3 2}$ & $\mathbf{0 . 0 9}$ \\
\hline $\mathbf{8}$ & 1 & 5 & 3 & 1 & 0 & 3 & 0 & $\mathbf{1}$ & 0 & 0 & 0 & 0 & 0 & 0 & 0 & 1 & $\mathbf{1 5}$ & $\mathbf{0 . 0 7}$ \\
\hline $\mathbf{9}$ & 25 & 8 & 4 & 2 & 0 & 42 & 10 & 5 & $\mathbf{5 9}$ & 8 & 25 & 3 & 0 & 0 & 2 & 12 & $\mathbf{2 0 5}$ & $\mathbf{0 . 2 9}$ \\
\hline $\mathbf{1 0}$ & 0 & 24 & 0 & 0 & 0 & 1 & 0 & 0 & 2 & $\mathbf{1}$ & 1 & 6 & 1 & 0 & 0 & 1 & $\mathbf{3 7}$ & $\mathbf{0 . 0 3}$ \\
\hline $\mathbf{1 1}$ & 1 & 1 & 0 & 0 & 0 & 1 & 0 & 0 & 0 & 0 & $\mathbf{3}$ & 0 & 0 & 0 & 0 & 0 & $\mathbf{6}$ & $\mathbf{0 . 5 0}$ \\
\hline $\mathbf{1 2}$ & 0 & 0 & 0 & 0 & 0 & 0 & 0 & 0 & 0 & 8 & 0 & $\mathbf{8}$ & 0 & 0 & 0 & 0 & $\mathbf{1 6}$ & $\mathbf{0 . 5 0}$ \\
\hline $\mathbf{1 3}$ & 0 & 0 & 0 & 0 & 0 & 0 & 0 & 0 & 0 & 0 & 0 & 1 & $\mathbf{0}$ & 0 & 0 & 0 & $\mathbf{1}$ & $\mathbf{0 . 0 0}$ \\
\hline $\mathbf{1 4}$ & 0 & 0 & 7 & 0 & 0 & 0 & 0 & 0 & 0 & 0 & 0 & 0 & 0 & $\mathbf{7}$ & 0 & 0 & $\mathbf{1 4}$ & $\mathbf{0 . 5 0}$ \\
\hline $\mathbf{1 5}$ & 0 & 1 & 0 & 0 & 0 & 0 & 0 & 0 & 2 & 0 & 0 & 0 & 0 & 0 & $\mathbf{2 7}$ & 25 & $\mathbf{5 5}$ & $\mathbf{0 . 4 9}$ \\
\hline $\mathbf{1 6}$ & 1 & 0 & 0 & 2 & 0 & 0 & 0 & 0 & 0 & 1 & 0 & 0 & 0 & 0 & 0 & $\mathbf{3 3}$ & $\mathbf{3 7}$ & $\mathbf{0 . 8 9}$ \\
\hline Tot & $\mathbf{5 6}$ & $\mathbf{8 5}$ & $\mathbf{5 7}$ & $\mathbf{2 8}$ & $\mathbf{0}$ & $\mathbf{8 3}$ & $\mathbf{2 6}$ & $\mathbf{1 4}$ & $\mathbf{7 1}$ & $\mathbf{2 2}$ & $\mathbf{3 5}$ & $\mathbf{2 0}$ & $\mathbf{1}$ & $\mathbf{9}$ & $\mathbf{2 9}$ & $\mathbf{1 3 1}$ & $\mathbf{6 6 7}$ & \\
\hline Users & $\mathbf{0 . 1 6}$ & $\mathbf{0 . 3 3}$ & $\mathbf{0 . 3 3}$ & $\mathbf{0 . 4 3}$ & $\mathbf{0 . 0 0}$ & $\mathbf{0 . 2 9}$ & $\mathbf{0 . 1 2}$ & $\mathbf{0 . 0 7}$ & $\mathbf{0 . 8 3}$ & $\mathbf{0 . 0 5}$ & $\mathbf{0 . 0 9}$ & $\mathbf{0 . 4 0}$ & $\mathbf{0 . 0 0}$ & $\mathbf{0 . 7 8}$ & $\mathbf{0 . 9 3}$ & $\mathbf{0 . 2 5}$ & & $\mathbf{0 . 3 5}$ \\
\hline
\end{tabular}

Table 5. Subgroup/Group/Subclass error matrix.

\begin{tabular}{|c|c|c|c|c|c|c|c|c|c|c|c|c|}
\hline & 1 & 2 & 3 & 4 & 5 & 6 & 7 & 8 & 9 & 10 & Tot & Prod \\
\hline 1 & 9 & 5 & 9 & 1 & 0 & 4 & 0 & 0 & 0 & 3 & 31 & 0.29 \\
\hline 2 & 4 & 79 & 12 & 3 & 0 & 0 & 0 & 2 & 0 & 44 & 144 & 0.55 \\
\hline 3 & 16 & 37 & 43 & 4 & 4 & 2 & 2 & 0 & 0 & 13 & 121 & 0.36 \\
\hline 4 & 25 & 14 & 57 & 59 & 8 & 25 & 3 & 0 & 2 & 12 & 205 & 0.29 \\
\hline 5 & 0 & 24 & 1 & 2 & 1 & 1 & 6 & 1 & 0 & 1 & 37 & 0.03 \\
\hline 6 & 1 & 1 & 1 & 0 & 0 & 3 & 0 & 0 & 0 & 0 & 6 & 0.50 \\
\hline 7 & 0 & 0 & 0 & 0 & 8 & 0 & 8 & 0 & 0 & 0 & 16 & 0.50 \\
\hline 8 & 0 & 7 & 0 & 0 & 0 & 0 & 1 & 7 & 0 & 0 & 15 & 0.47 \\
\hline 9 & 0 & 1 & 0 & 2 & 0 & 0 & 0 & 0 & 27 & 25 & 55 & 0.49 \\
\hline
\end{tabular}




\begin{tabular}{|l|r|r|r|r|r|r|r|r|r|r|r|r|}
\hline 10 & 1 & 2 & 0 & 0 & 1 & 0 & 0 & 0 & 0 & 33 & 37 & 0.89 \\
\hline Tot & 56 & 170 & 123 & 71 & 22 & 35 & 20 & 10 & 29 & 131 & 667 & \\
\hline Users & 0.16 & 0.47 & 0.35 & 0.83 & 0.05 & 0.09 & 0.40 & 0.70 & 0.93 & 0.25 & & 0.40 \\
\hline
\end{tabular}

Table 6. Class error matrix.

\begin{tabular}{|c|c|c|c|c|c|c|c|}
\hline & 1 & 2 & 3 & 4 & 5 & Tot & Prod \\
\hline 1 & 214 & 18 & 4 & 0 & 60 & 296 & 0.72 \\
\hline 2 & 124 & 99 & 10 & 2 & 13 & 248 & 0.40 \\
\hline 3 & 7 & 8 & 16 & 0 & 0 & 31 & 0.52 \\
\hline 4 & 1 & 2 & 0 & 27 & 25 & 55 & 0.49 \\
\hline 5 & 3 & 1 & 0 & 0 & 33 & 37 & 0.89 \\
\hline Tot & 349 & 128 & 30 & 29 & 131 & 667 & \\
\hline Users & 0.61 & 0.77 & 0.53 & 0.93 & 0.25 & & 0.58 \\
\hline
\end{tabular}

Table 7. NIMA error matrix.

\begin{tabular}{|c|c|c|c|c|c|c|c|c|}
\hline & 1 & 2 & 3 & 4 & 5 & 6 & Tot & Prod \\
\hline 1 & 16 & 0 & 15 & 0 & 0 & 0 & 31 & 0.52 \\
\hline 2 & 6 & 71 & 20 & 72 & 4 & 0 & 173 & 0.41 \\
\hline 3 & 9 & 9 & 133 & 31 & 0 & 0 & 182 & 0.73 \\
\hline 4 & 5 & 27 & 68 & 86 & 1 & 3 & 190 & 0.45 \\
\hline 5 & 1 & 0 & 2 & 4 & 39 & 14 & 60 & 0.65 \\
\hline 6 & 0 & 0 & 3 & 0 & 1 & 27 & 31 & 0.87 \\
\hline Tot & 37 & 107 & 241 & 193 & 45 & 44 & 667 & \\
\hline User & 0.43 & 0.66 & 0.55 & 0.45 & 0.87 & 0.61 & & 0.56 \\
\hline
\end{tabular}

Table 8. Summary accuracy table.

\begin{tabular}{|l|c|c|}
\hline & Kappa & Overall \\
\hline Alliance & 0.20 & 0.22 \\
Formation & 0.29 & 0.35 \\
Subgroup/Group/Subclass & 0.30 & 0.40 \\
Class & 0.39 & 0.58 \\
NIMA & 0.42 & 0.56 \\
\hline
\end{tabular}

With respect to spatial accuracy, the root mean square error for the 40 control points evaluated was 69.4 meters. This number should be considered as an overstatement of the actual spatial error given that the reference data (the Fort Benning road coverage) most likely is not error-free and that the subject vegetation map does not explicitly show road intersections. The actual spatial error is probably less than 60 meters. 


\section{Discussion}

The alliance-level accuracy of the Fort Benning vegetation map is estimated to be 22 percent. From a practical standpoint, an alliance level accuracy of 70 percent should be considered a minimum level, with a map accuracy of 90 to 95 percent recommended. A Kappa value between 0.4 and 0.75 suggests a moderately accurate map; however, an overall NI MA Kappa of 42 percent indicates the map is only marginally acceptable at even this relatively broad scale. The discrepancy between the current map's overall accuracy and the minimum accuracy indicates the possibility of numerous error sources. Those error sources are related to the vegetation classification system, registration of aerial photographs and other mapping procedures, and error analysis procedures. The vegetation dassification system used in the original compilation of the F ort Benning vegetation map was a draft version of a TNC document (Weakley et al. 1996) describing a classification of the terrestrial vegetation of the southeastern United States. Since that classification system was superceded by a 1998 TNC document, the Fort Benning vegetation map was reclassified into the newer system for accuracy assessment purposes.

Given the floristic complexity of Fort Benning and the incomplete alliance descriptions, thematic error could have been introduced during the classification system crosswalking procedures. Classification system uncertainty was evident during field sampling using the key developed by TNC in 1998 as indicated by the large number of plots that were not classified. The TNC system tends to focus on natural vegetation communities and gives lesser emphasis to anthropogenically-modified vegetation types common on Fort Benning. In general, the functionality of the field key used to identify the sample plots was good. The distinction between forest and woodland was sometimes difficult, particularly in Pinus taeda-dominated alliances. Some of this difficulty could be expected due to timber thinning and other disturbances occurring during the gap of more than 5 years between initial map development and fieldwork. The primary difficulty encountered in the field was the lack of choices at the alliance level. This perception could be the result of encountering alliances not previously identified as occurring on Fort Benning, and alliances thought to occur but which may not. Two such alliances in the field key not found on Fort Benning are: Fagus grandifolia - Quercus alba Forest Alliance (\#4) and Quercus shumardii - Q. pagoda Forest Alliance (\#12). A more detailed vegetation analysis 
would be required to identify and describe additional alliances and/or verify the nonexistence of others.

The Fort Benning vegetation map was compiled by standard photo analysis procedures using 1:12,000 color infrared (CIR) aerial photography taken in J anuary of 1993 during leaf-off conditions (Geo-Marine, Inc., 1996). The base maps for the project were 7.5-minute USGS topographic quandrangles covering Fort Benning. Both the aerial photography and base maps were suboptimal and likely error sources. A recommended set of source data would have been CIR, leaf-on, stereoscopic photography at scales of 1:12,000 and greater for alliance interpretation and digital orthophoto mosaics for geodetic base purposes. The addition of near-infrared reflectance information, deciduous leaf morphology, and superior geometric accuracy provided by these alternative source materials would have very likely resulted in higher map accuracy. Additional field time for the photo interpretation analysts in collaboration with vegetation ecologists would also have promoted higher map accuracy. An important lesson to learn from this project is the value of quantitative field data collected on military lands in the development of regional classification systems. Field data collected during this project and, even more substantially, through Fort Benning's Land Condition Trend Analysis (LCTA) program have added much needed information to the southeastern vegetation database. Moreover, photo analysis must be based on a sound understanding of the complexity and diversity of actual field vegetation conditions so that image analysts can reliably correlate photo signatures with alliance types.

A source for the error analysis procedures used in this project is the USGS/NPS National Vegetation Mapping Program. Using these guidelines, a sampling design was created that proved difficult to fully implement. Due to map error, dassification system ambiguities, logistic complications, and insufficient resources, the majority of alliance types were substantially undersampled. Class accuracy values associated with substantially undersampled alliances should be used with much discretion. In addition to undersampling, a clear source of bias on active military training and testing lands such as Fort Benning is the time delay between source imagery collection and field assessment. In this project, approximately $5 \frac{1 / 2}{2}$ years passed between image acquisition and fieldwork. Within this extended period, both natural and anthropogenic events occurred on Fort Benning. Adding to the temporal error is spatial error resulting from the interacting influences of 20-meter average GPS position errors and the inherent error in locating image patterns observed in the aerial photography on topographic maps. A final error source could be discrepancies between field and air photo estimation of canopy cover, a critical split variable in the TNC 
dassification system. Past experience indicates that field cover estimates are generally lower than aerial estimates. 


\section{Recommendations}

The results of this study, while not especially supportive of the current vegetation map, do provide some important lessons learned. The following recommendations reflect those lessons and are made for the benefit of future mapping projects on military reservations:

1. Use a stable, site-specific dassification system that fully represents the vegetation communities found on the mapping project area.

This often is not possible on military lands for areas that have been previously unmapped, and is a challenge for an alliancelevel mapping project due to emerging state-of-the-art of vegetation classification systems. Rather, military installations often provide data augmenting recognized vegetation databases such as the Natural Heritage database. Adoption and support of the NVCS, of which the TNC southeastern classification system is an important precursor, is the recommended long-term approach to solving this problem. The process for field data collection, data analysis, alliance description, and problem adjudication currently in work by the Ecological Society of America in support of the NVCS will eventually provide a framework for resolving this issue. It is recommended that LCTA activities on military training and testing lands incorporate and support the NVCS system and associated procedures.

2. Acquire and use large-scale, leaf-on photography.

Vegetation mapping at the alliance level mandates the discrimination of dominant plant species from imagery sources. This extremely difficult task requires the use of large-scale photography (ideally) both in leaf-on and leafoff condition. Leaf-on photography provides clues about tree crown shape and leaf morphology, facilitating the separation of closely related alliances. The combined use of leaf-on and leaf-off photography ensures accurate separation of evergreen and deciduous types and their associated alliances.

3. Acquire and use digital orthophotographs as the geodetic base map.

Standard aerial photography exhibits geometric displacement due to variations in distance from the photo center point (tilt displacement) and topography (relief displacement). These error sources must be reconciled when producing vegetation maps to ensure adequate spatial accuracy. The 
preferred solution from a technical perspective is to use orthorectified image base maps in which tilt and relief displacement have been removed through standard photogrammetric practices. Use of imagery-based mosaics is especially helpful in the accurate transfer of patterns found in the unrectified, stereoscopic, aerial photography. The disadvantage to digital orthophoto bases is cost: standard, easily affordable orthophotos available from the USGS may not have sufficient spatial resolution for alliancelevel vegetation mapping while custom orthophoto mosaics tend to be expensive.

4. Allow time for substantial field reconnaissance and polygon label validation by a joint team of vegetation ecologists and photointerpretation analysts.

In the original compilation of the Fort Benning vegetation map, limited resources greatly constrained the amount of local floral expertise available during the photo interpretation procedures. Ideally, a vegetation mapping project has three phases involving extended field time: initial reconnaissance, intermediate validation, and post-mapping accuracy assessment. The validation phase is particularly important to map accuracy so that preliminary alliance assignments can be field checked to ensure that photo patterns are being reliably correlated with vegetation types. The validation phase can also serve as a time to address perceived deficiencies in the classification system and to deal with alliance types that cannot accurately be identified from aerial photography. Close tracking of field progress is essential to minimize or avoid oversampling and undersampling.

5. Improve the cost estimation for reference data collection.

An accurate estimate of the amount of funding necessary to perform a rigorous accuracy assessment was not accomplished for this project. While it is true that some of the undersampling of alliance types was due to poor map quality and underestimation of required field resources, it also became evident that considerably greater funding was necessary to fully satisfy the USGS/NPS sampling protocols. Based on 60 percent sampling of the target pool achieved in this project, it is reasonable to conclude that approximately twice as much funding would be required on a similar project.

6. Integrate map compilation and accuracy assessment.

This coupling of the two elements is highly recommended. If this is not possible, conduct the accuracy assessment within a reasonable amount of time following creation of the vegetation map, especially on areas where environmental impacts are significant.

The vegetation on military reservations can be highly dynamic due to military training and natural resource management activities. These dynamics 
not only include natural (and generally predictable) plant community succession, but also human-induced environmental perturbations such as ordinance firing and off-road driving impacts, accidental fires, TES habitat improvements, and commercial forestry activities. Some environmental impacts can merely delay natural community succession, while others can transform areas to earlier successional stages. Thus, to minimize temporal error and maximize the accuracy of future installation vegetation maps, proponents of vegetation mapping programs should consider accuracy assessments to be a core requirement in the vegetation mapping process. 


\section{Literature Cited}

Army Regulation (AR) 200-3, Natural Resources-Land, Forest, and Wildlife Management (Headquarters, Department of the Army [HQDA], Washington, DC, February 1995).

AR 350-4, Integrated Training Area Management (ITAM), HQDA, Washington, DC, 8 May 1998.

Department of the Army Memo, Assistant Chief of Staff for Installation Management, "Army Goals and I mplementing Guidance for Natural Resources Management Planning Level Surveys and Integrated Natural Resource Management Plans," 21 March 1997.

Department of Defense (DoD) Instruction 4715.3, Environmental Conservation Program (Department of Defense, 3 May 1996).

Geo-Marine, Inc. 1996. "Vegetation Community Mapping from Color Infrared Arial Photography of Fort Benning, Georgia." Final Report Prepared for U.S. Army Construction Engineering Research Laboratory (CERL), Champaign, IL. Purchase order No. DACW88-92-R-0010. GeoMarine, Inc., Plano, TX.

Geo-Marine, Inc. 1997a. "Fort Benning Vegetation Classification and Mapping: ARC/INFO Coverages and AMLs." Prepared for U.S. Army Construction Engineering Research Laboratory (CERL), Champaign, IL. Purchase order No. DACW88-98-M-0088. Geo-Marine, Inc., Plano, TX.

Geo-Marine, Inc. 1997b. "F ort Benning Vegetation Mapping and Classification: Cross-walk Tables and Attribute Assignments." Prepared for U.S. Army Construction Engineering Research Laboratory (CERL), Champaign, IL. Purchase order No. DACW88-98-M-0088. Geo-Marine, Inc., Plano, TX.

Headquarters, Department of the Army, Office of the Deputy Chief of Staff for Operations and Plans, "Integrated Training Area Management (ITAM) Program Strategy," 17 August 1995.

Tazik, D.J ., S.D. Warren, V.E. Diersing, R.B. Shaw, R.J . Brozka, C.F. Bagley, and W.R. Whitworth. 1992. US Army Land Condition-Trend Analysis (LCTA) Plot I nventory Field Methods. CERL Technical Report N-92/03, Champaign, IL.

The Nature Conservancy (TNC) and E nvironmental Systems Research Institute (ESRI) for U.S. Department of the Interior, "Standardized National Vegetation Classification System. NBS/NPS Vegetation Mapping Program," Final draft, November 1994a.

TNC and ESRI for U.S. Department of the Interior, "Accuracy Assessment Procedures. NBS/NPS Vegetation Mapping Program," Final draft, November 1994b. 
TNC. 1998. International Classification of Ecological Communities: Terrestrial Vegetation of the Southeastern United States, Fort Benning Subset. The Nature Conservancy, Community Ecology Group, Southeastern Conservation Science Department, Chapel Hill, NC.

Weakley, A.S., K.D. Patterson, S. Landaal, M. Pyne, and others (compilers). 1996. "International Classification of Ecological Communities: Terrestrial Vegetation of the Southeastern United States." Working draft of April 1996. The Nature Conservancy, Southeast Regional Office, Southern Conservation Science Department, Community Ecology Group, Chapel Hill, NC.

16 U.S. Code, Chapter 56, Conservation Programs on Government Lands, Sub-Chapter 1, Conservation Programs on Military Reservations, paragraphs 670a-670o, commonly know as The Sikes Act. 


\section{Appendix A: Common Names for the Woody Plant Species Found in the Field Key}

\begin{tabular}{|c|c|}
\hline SCIENTIFIC NAME & COMMON NAME \\
\hline Acer rubrum & Red maple \\
\hline Acer saccharinum & Silver maple \\
\hline Alnus serrulata & Hazel alder \\
\hline Andropogon virginicus & Broomsedge bluestem \\
\hline Arundinaria gigantea & Giant cane \\
\hline Betula nigra & River birch \\
\hline Carya glabra & Pignut hickory \\
\hline Carya illinoensis & Pecan \\
\hline Carya ovata & Shagbark hickory \\
\hline Carya pallida & Sand hickory \\
\hline Carya tomentosa & Mockernut hickory \\
\hline Celtis laevigata & Soapberry \\
\hline Celtis occidentalis & Hackberry \\
\hline Cornus florida & Flowering dogwood \\
\hline Crataegus crus-galli & Cockspur hawthorn \\
\hline Crataegus marshallii & Parsley hawthorn \\
\hline Crataegus spathulata & Littlehip hawthorn \\
\hline Diosporus virginiana & Common persimmon \\
\hline Fagus grandifolia & American beech \\
\hline Fraxinus pennsylvanica & Green ash \\
\hline Gordonia lasianthus & Loblolly bay \\
\hline Juniperus virginiana & Eastern red cedar \\
\hline Liquidambar styraciflua & Sweetgum \\
\hline Liriodendron tulipifera & Yellow polar; Tuliptree \\
\hline Magnolia grandiflora & Southern magnolia \\
\hline Magnolia virginiana & Sweetbay \\
\hline Myrica cerifera & Southern bayberry \\
\hline Nyssa aquatica & Water tupelo \\
\hline Nyssa biflora & Swamp tupelo \\
\hline Nyssa ogeche & Ogeechee tupelo \\
\hline Nyssa sylvatica & Black tupelo \\
\hline Persea palustris & Swamp bay \\
\hline Pinus echinata & Shortleaf pine \\
\hline Pinus elliottii & Slash pine \\
\hline Pinus palustris & Longleaf pine \\
\hline
\end{tabular}




\begin{tabular}{|l|l|}
\hline SCIENTIFIC NAME & COMMON NAME \\
\hline Pinus serotina & Pond pine \\
\hline Pinus taeda & Loblolly pine \\
\hline Platanus occidentalis & Sycamore \\
\hline Prunus angustifolia & Chickasaw plum \\
\hline Quercus alba & White oak \\
\hline Quercus falcata & Southern red oak \\
\hline Quercus incana & Bluejack oak \\
\hline Quercus laevis & Turkey oak \\
\hline Quercus laurifolia & Laurel oak \\
\hline Quercus margarettiae & Shrubby post oak \\
\hline Quercus marilandica & Blackjack oak \\
\hline Quercus michauxii & Swamp chestnut oak \\
\hline Quercus nigra & Water oak \\
\hline Quercus pagoda & Cherrybark oak \\
\hline Quercus phellos & Willow oak \\
\hline Quercus rubra & Northern red oak \\
\hline Quercus shumardii & Shumard oak \\
\hline Quercus stellata & Post oak \\
\hline Quercus velutina & Black oak \\
\hline Taxodium distichum & Baldcypress \\
\hline Ulmus americana & American elm \\
\hline
\end{tabular}




\title{
Appendix B: Alliance ID and Name
}

\author{
Alliance ID Alliance Name \\ $1 \quad$ Pinus echinata Forest Alliance \\ 2 Pinus palusris - P. elliotii Temperate Forest Alliance \\ $3 \quad$ Pinus taeda Forest Alliance \\ $4 \quad$ Fagus grandifolia - Quercus alba Forest Alliance \\ $5 \quad$ Fagus grandifolia - Quercus rubra - Quercus alba Forest Alliance \\ $6 \quad$ Liquidambar styraciflua Forest Alliance \\ $7 \quad$ Liriodendron tulipifera Forest Alliance \\ $8 \quad$ Quercus alba - (Q. nigra) Forest Alliance \\ 9 Quercus alba - (Q. rubra, Carya spp.) Forest Alliance \\ 10 Quercus falcata Forest Alliance \\ 11 Quercus laevis Forest Alliance \\ 12 Quercus shumardii - Quercus pagoda Forest Alliance \\ 13 Quercus stellata - Q. marilandica Forest Alliance \\ 14 Betula nigra - (Plantanus occidentalis) Temp. Flooded Forest Alliance \\ 15 Fraxinus pennsylvanica - (Ulmus americana) - Celtis (occidentalis, laevigata) \\ Temp. Flooded Forest Alliance \\ 16 Liquidambar styraciflua (Liriodendron tulipifera, Acer rubrum) Temp. Flooded \\ Forest Alliance \\ 17 Plantanus occidentalis- (Fraxinus pennsylvanica, Celtis laevigata, \\ Acer saccharinum) Temp. Flooded Forest Alliance \\ 18 Quercus (michuaxii, pagoda, shumardii) - Liquidambar styraciflua Temp. Flooded \\ Forest Alliance \\ 19 Quercus (phellos, nigra, laurifolia) - Temp. Flooded Forest Alliance \\ Nyssa (aquatica, biflora,ogeche) Floodplain Seasonally Flooded Forest Alliance \\ Nyssa aquatica - (Taxodium distichum) Semi-permanently Flooded Forest Alliance \\ Fagus grandifolia - Magnolia grandiflora Forest Alliance \\ Pinus echinata - Quercus (alba, falcata,stellata, velutina) Forest Alliance \\ Pinus echinata - Quercus stellata - Q. marilandica Forest Alliance \\ Pinus palustris - P. (echinata, taeda) - Quercus (incana, margarettiae,falcata, \\ laevis) Forest Alliance \\ Pinus taeda - (Liquidambar styraciflua, Liriodendron tulipifera) Forest Alliance \\ Pinus taeda - Quercus (alba, falcata, stellata) Forest Alliance \\ Pinus taeda - Quercus nigra Forest Alliance \\ Pinus taeda - Liriodendron tulipifera Temp. Flooded Forest Alliance \\ Pinus taeda - Quercus (phellos, nigra, laurifoli) Temp.Flooded Forest Alliance \\ Pinus taeda - Liquidambar styraciflua - Acer rubrum Saturated Forest Alliance \\ Pinus echinata Woodland Alliance \\ 33 Pinus palustris Woodland Alliance \\ $34 \quad$ Pinus palustris - Pinus (echinata, taeda) Woodland Alliance \\ $35 \quad$ Pinus palustris / Quercus spp. Woodland Alliance
}




$\begin{array}{cl}\text { Alliance ID } & \text { Alliance Name } \\ 36 & \text { Pinus taeda Woodland Alliance } \\ 37 & \text { Pinus serotina Saturated Woodland Alliance } \\ 38 & \text { Quercus laevis Woodland Alliance } \\ 39 & \text { Quercus stellata - Q.marilandica Woodland Alliance } \\ 40 & \text { Pinus echinata - Quercus (alba, falcata, stellata, velutina) Woodland Alliance } \\ 41 & \text { Pinus echinata - Quercus stellata - Q. marilandica Woodland Alliance } \\ 42 & \text { Myrica cerifera Seasonally Flooded Shrubland Alliance } \\ 43 & \text { Arundinaria gigantea Saturated Shrubland Alliance } \\ 44 & \text { Crataegus spathulata Shrubland Alliance } \\ 45 & \text { Prunus angustifolia Shubland Alliance } \\ 46 & \text { Alnus serrulata Temp. Flooded Shrubland Alliance } \\ 47 & \text { Andropogon virginicus Herbaceous Alliance } \\ 48 & \text { Carya illinoensis Plantation } \\ 49 & \text { Wildlife Clearing (maintained, Non-maintained) grasses } \\ 50 & \text { Bare ground } \\ 51 & \text { Water }\end{array}$




\section{Appendix C: ARC/INFO Macro Language Programs}

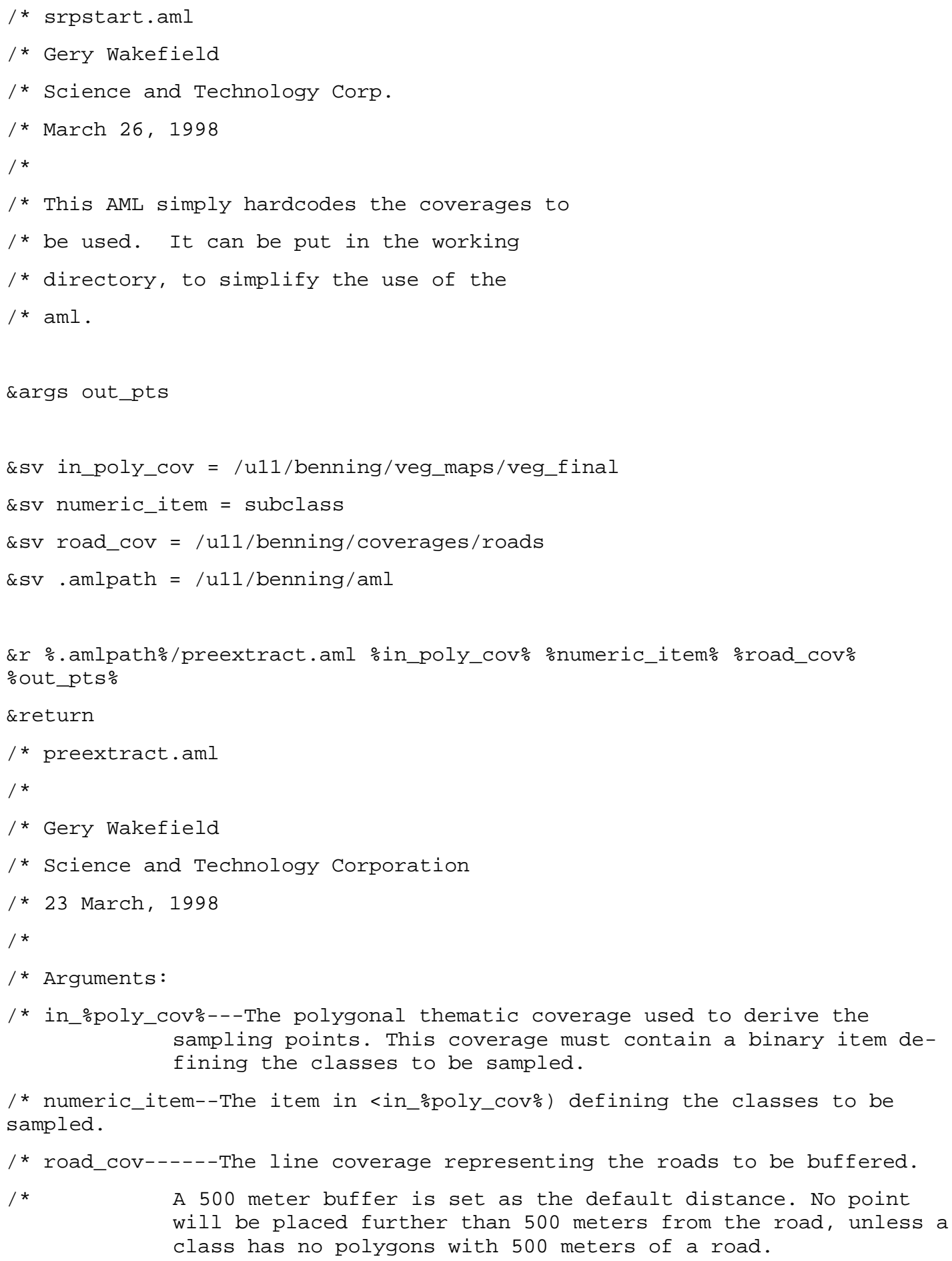




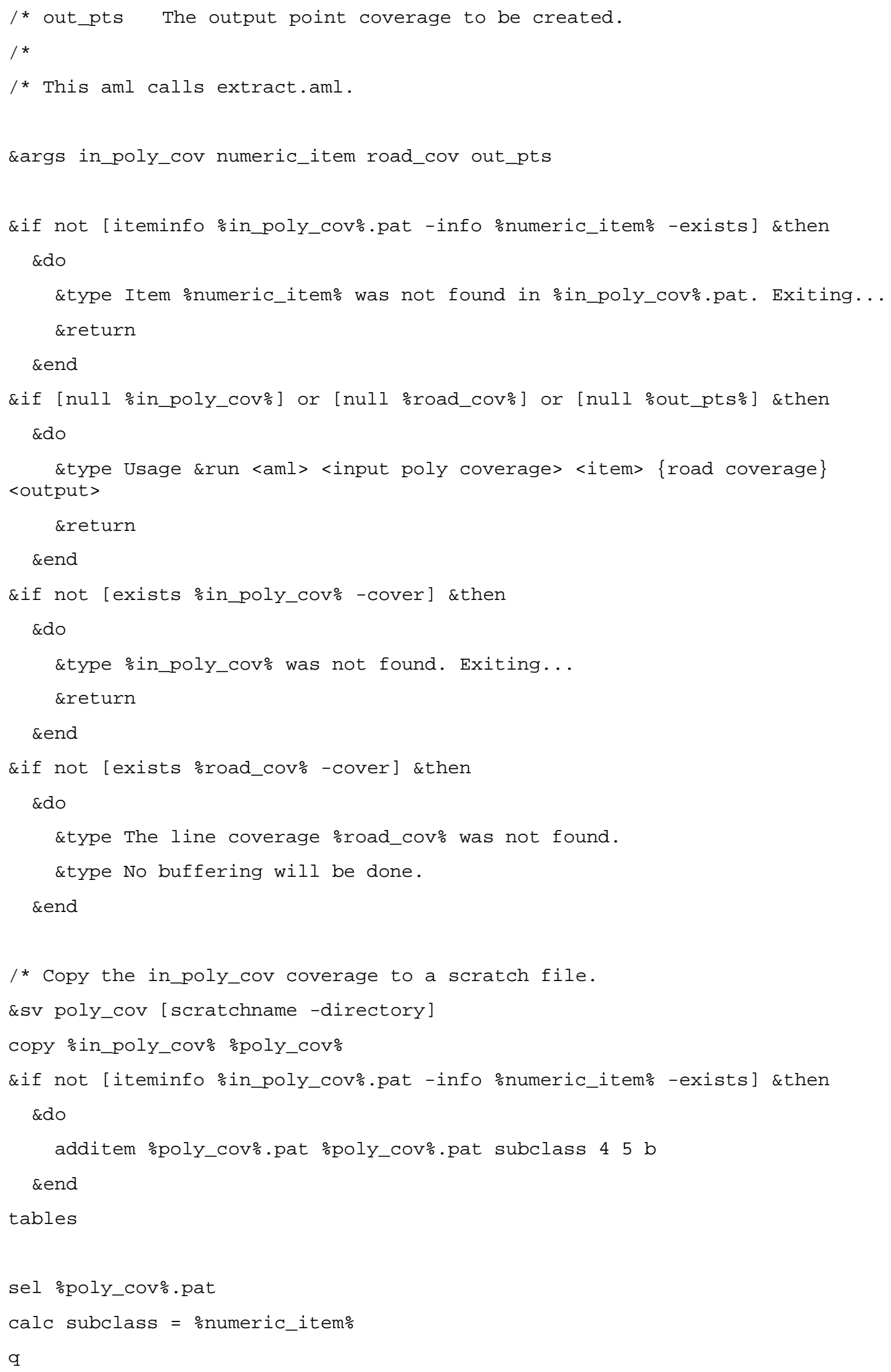




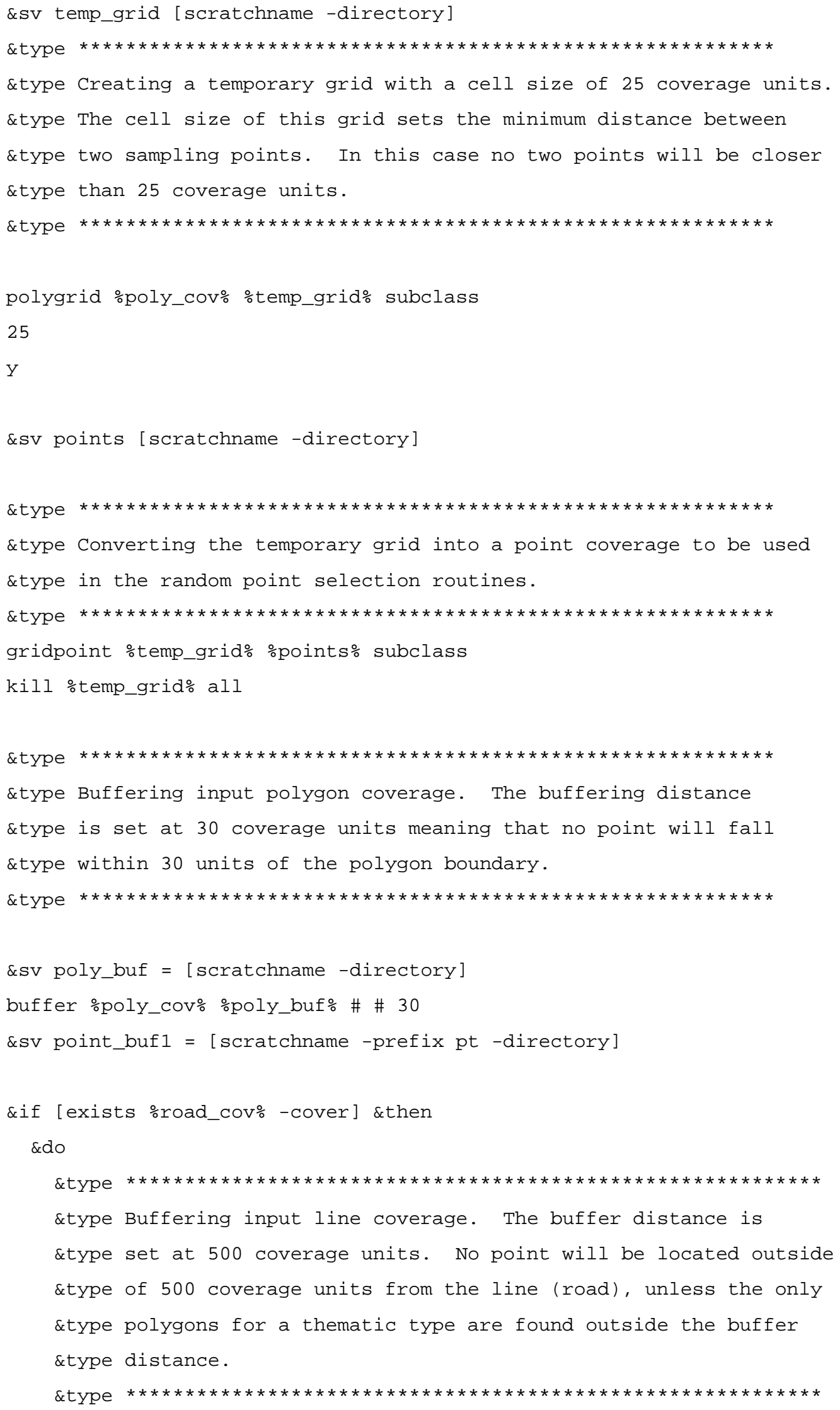




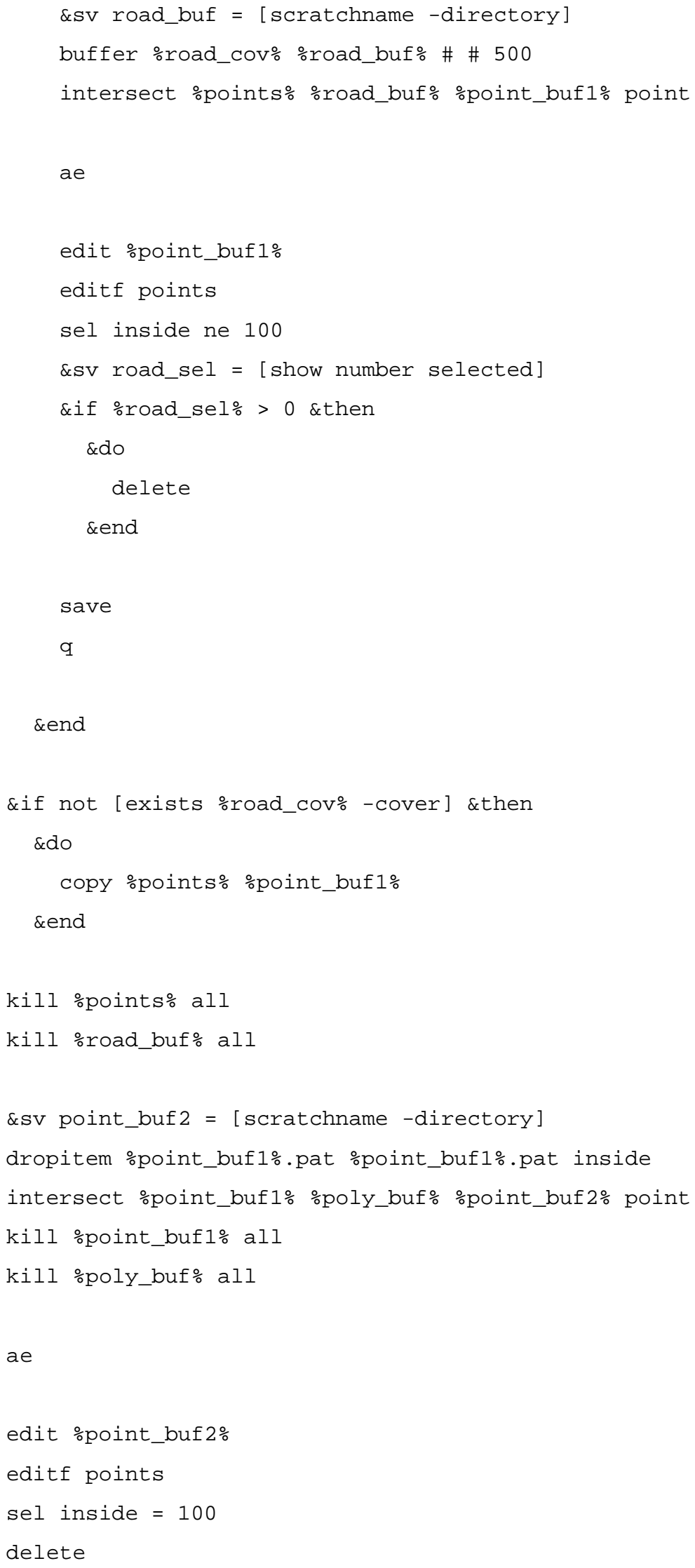




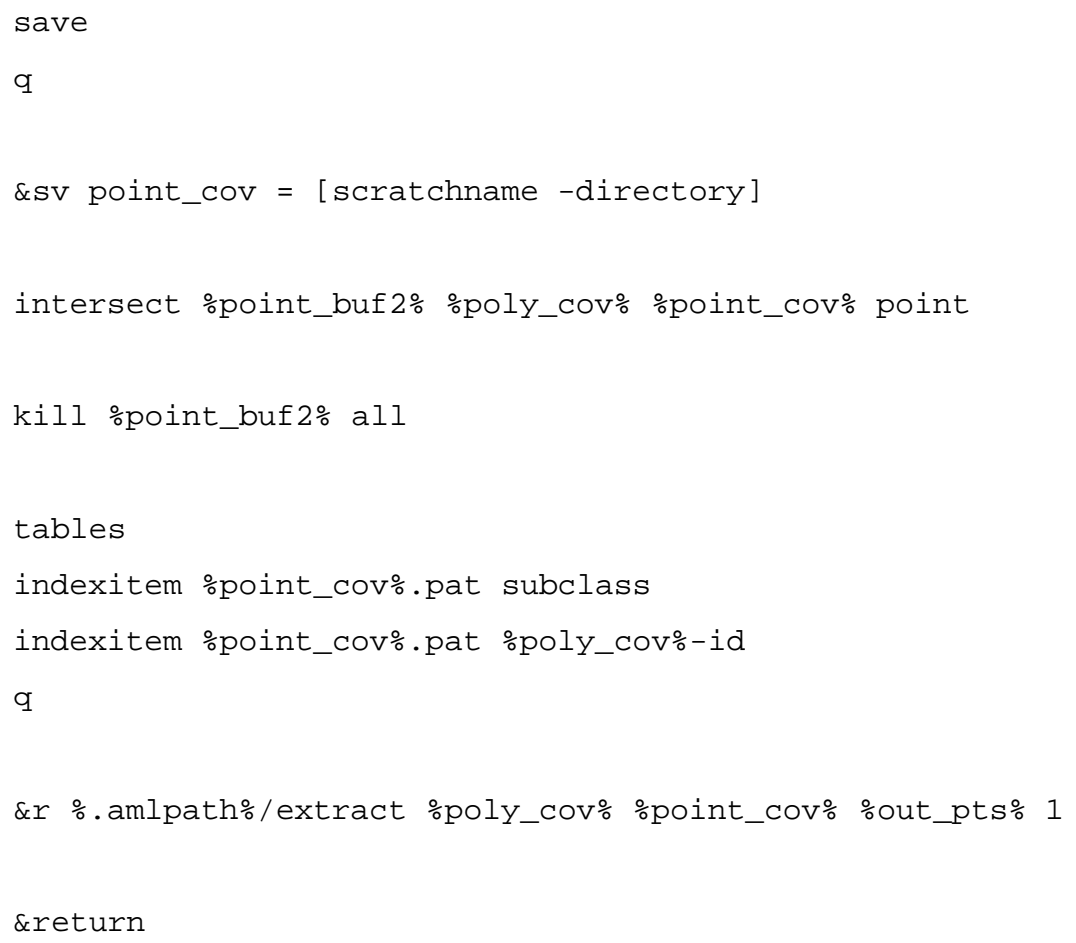




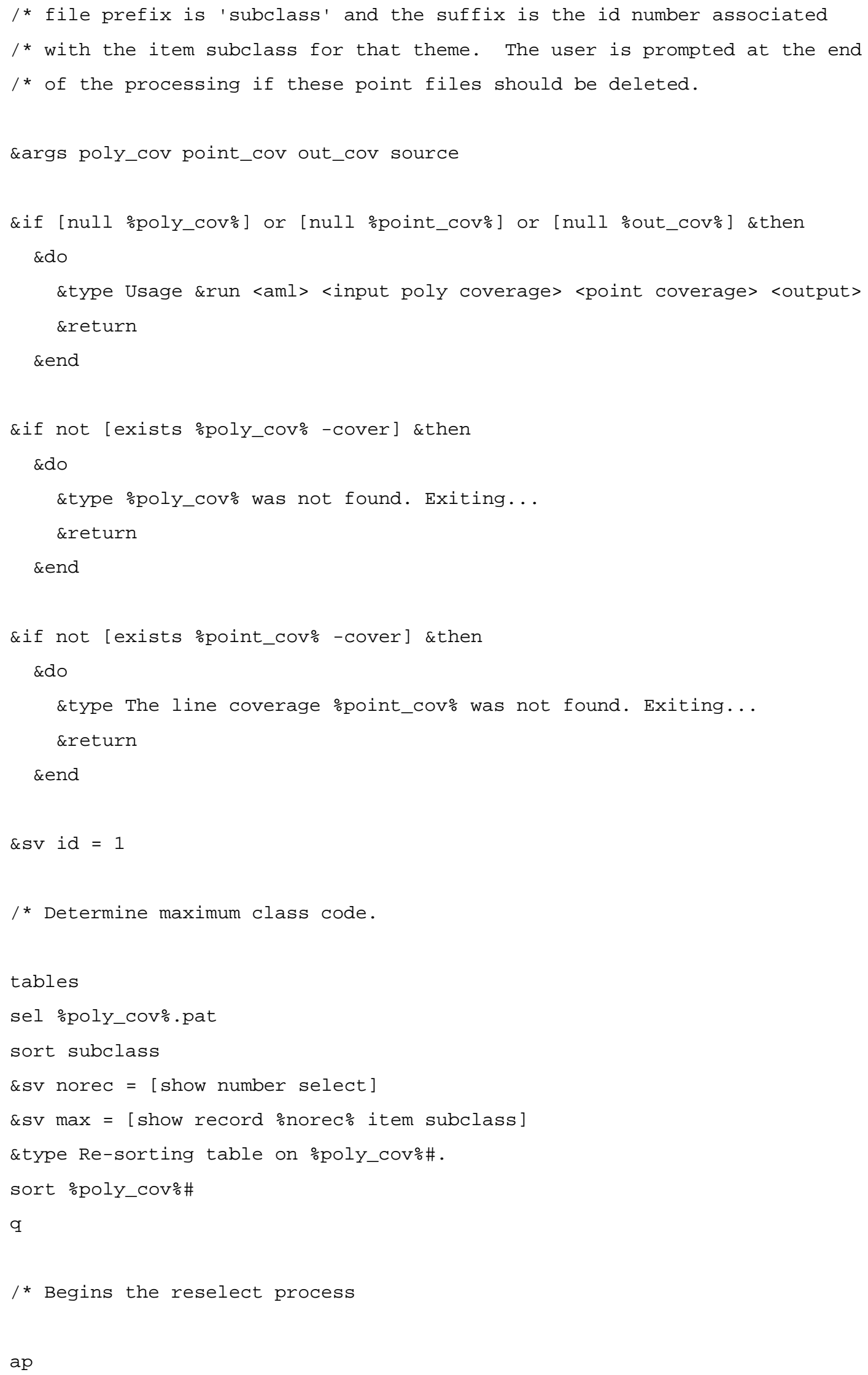




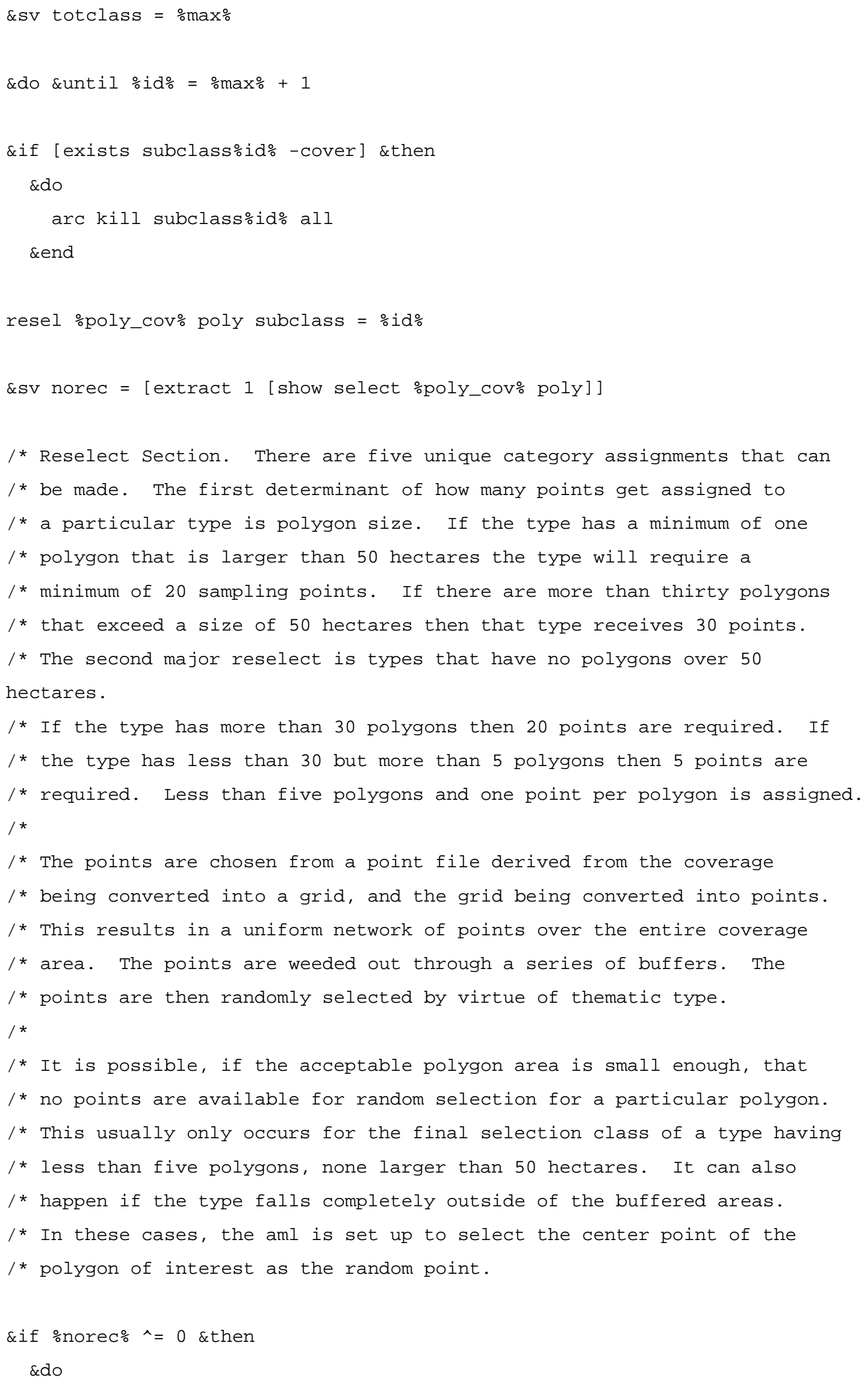




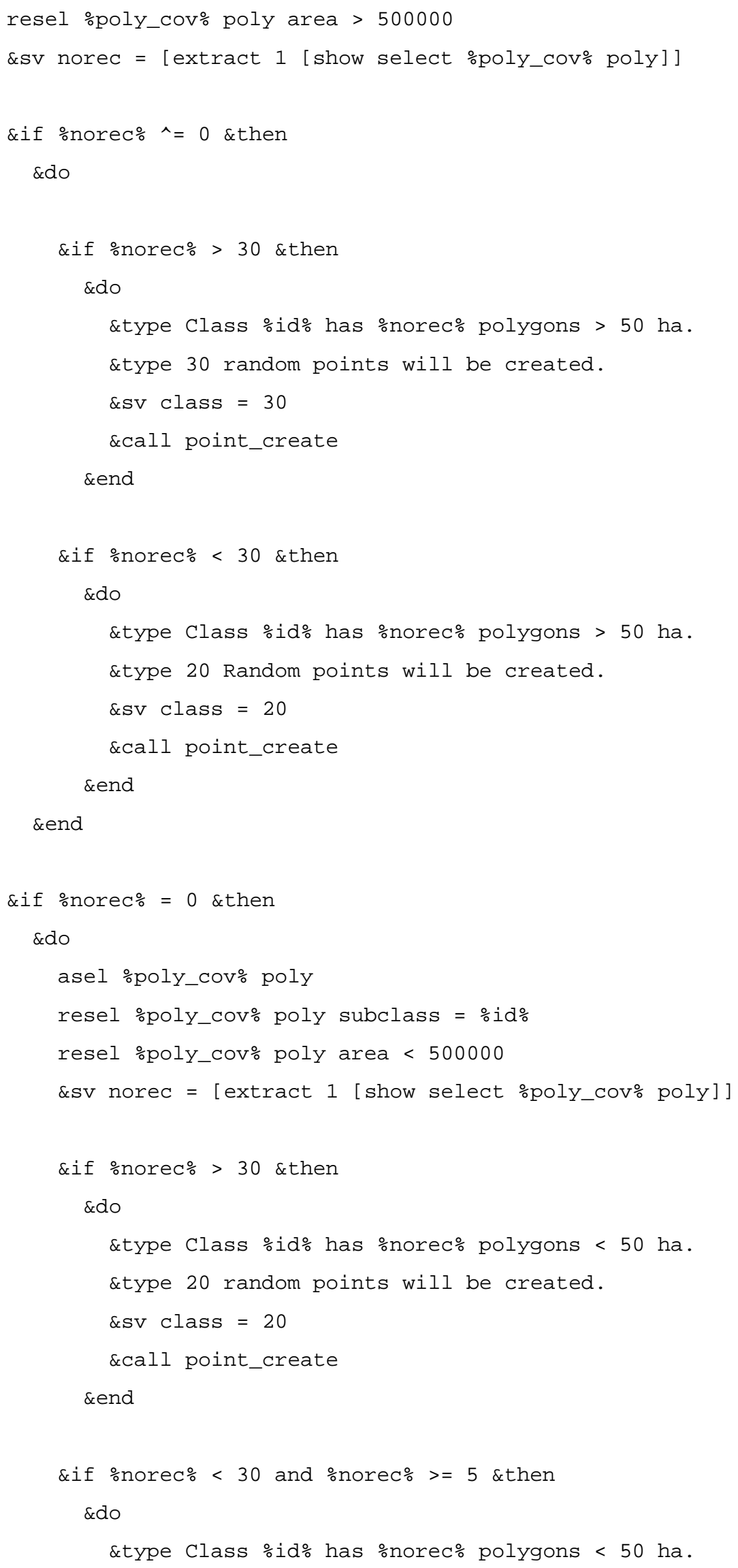


\&type 5 random points will be created.

$\& S V$ class $=5$

\&call point_create

\&end

\&if \%norec $\%<$ \&then

$\&$ do

\&type Class \%id\% has \%norec\% polygons < 50 ha.

\&type \%norec\% random points will be created.

\&SV class $=\frac{\circ}{\circ}$ norec $\%$

\&call point_per_poly_create

\&end

\&end

\&end

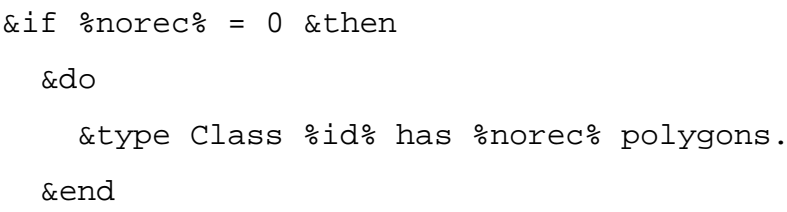




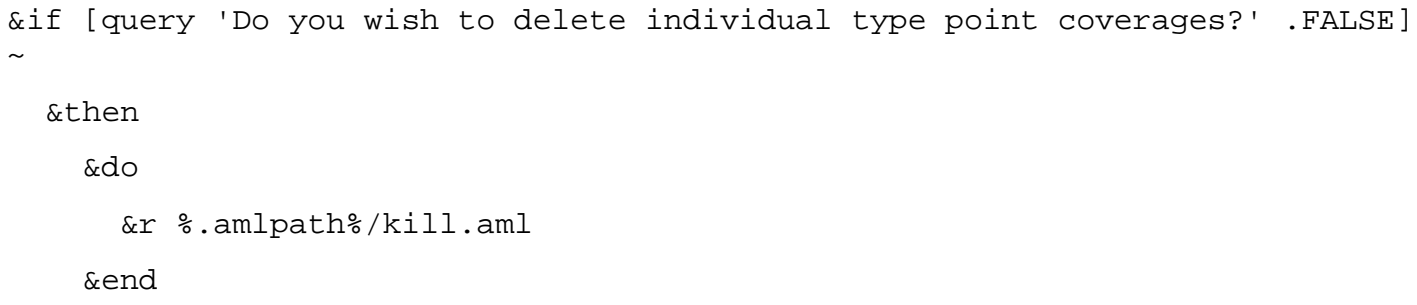




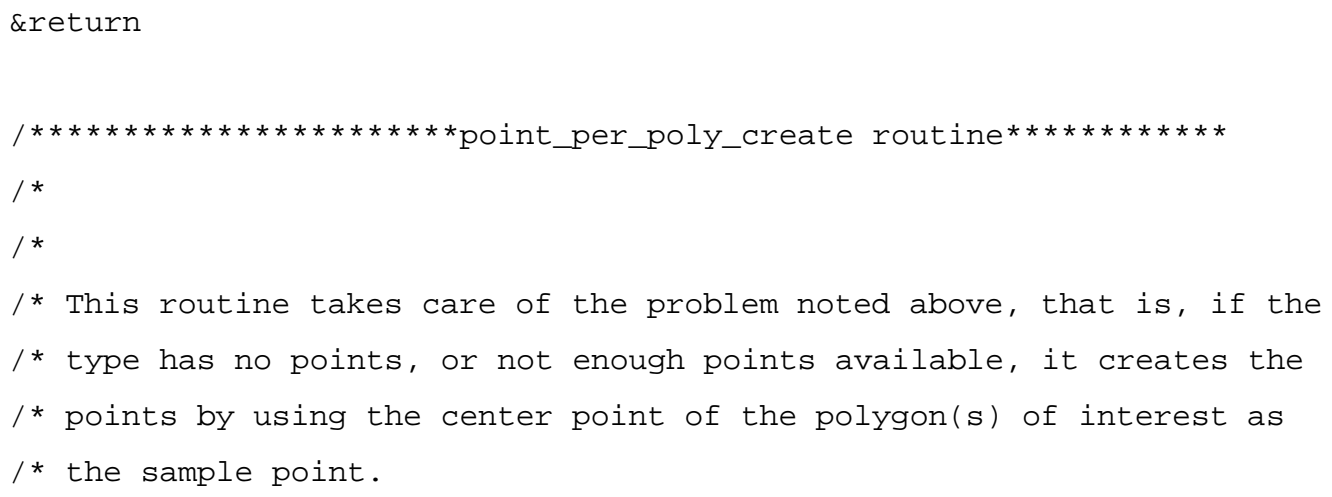




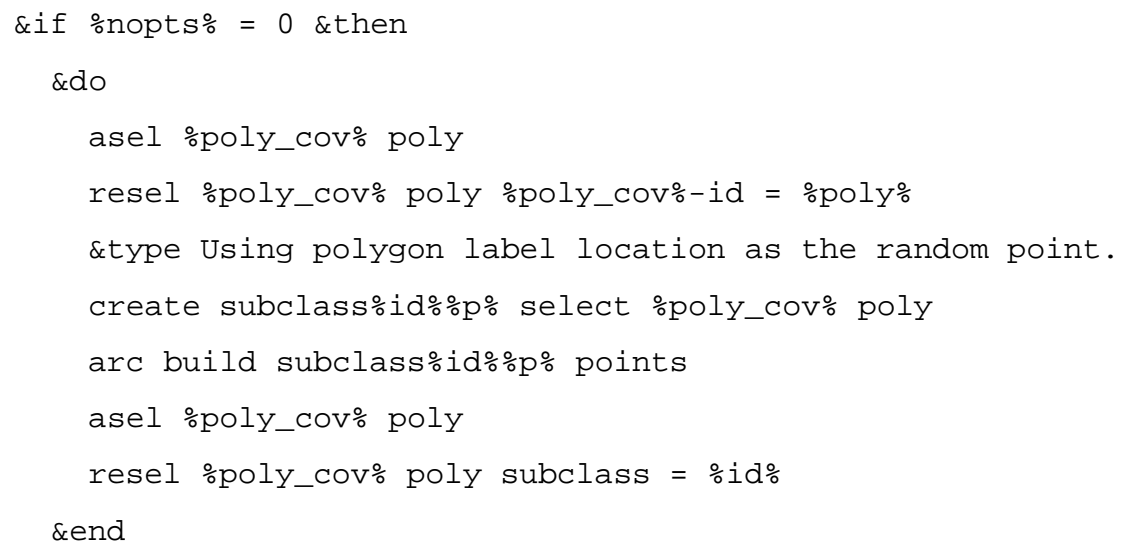




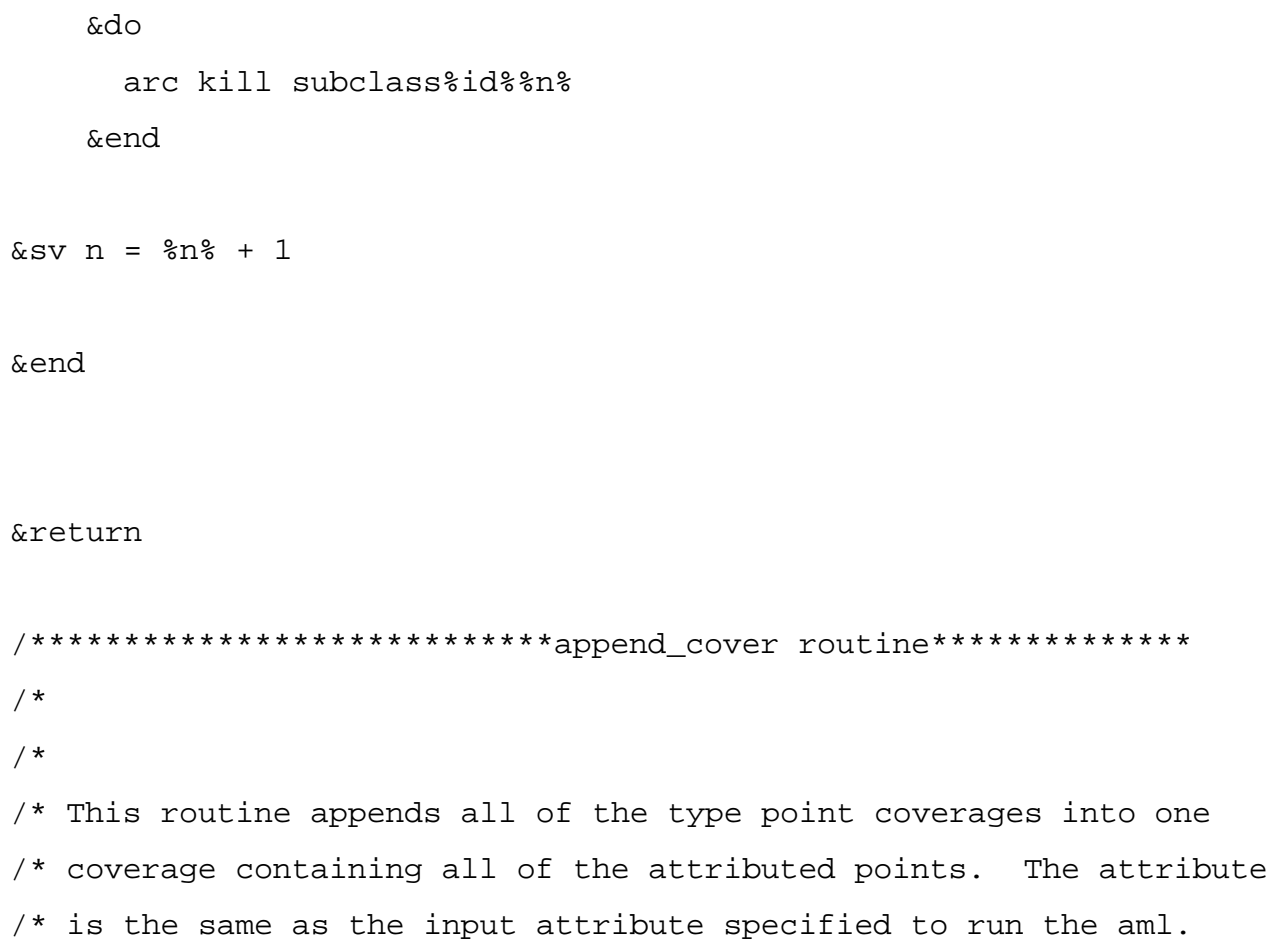




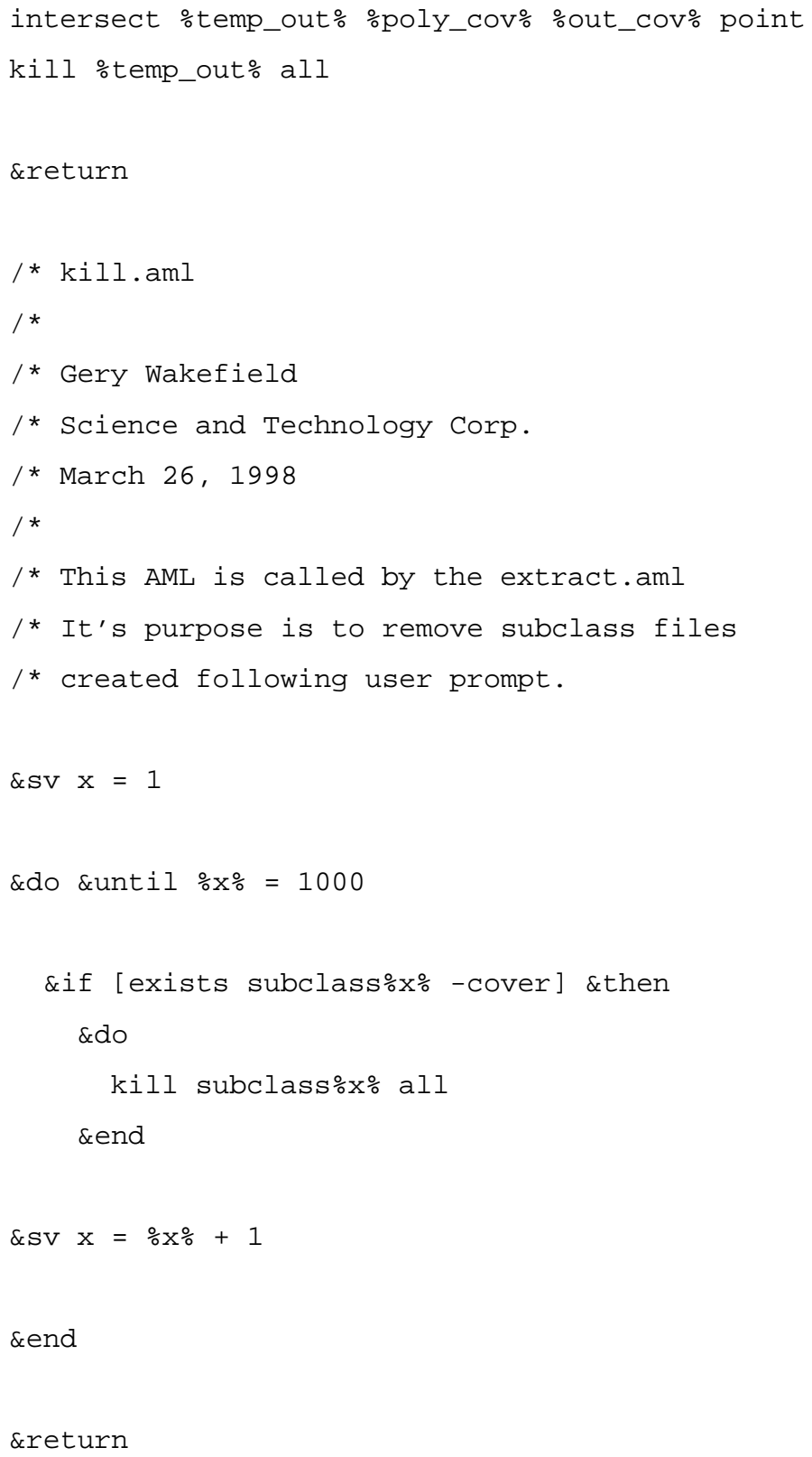




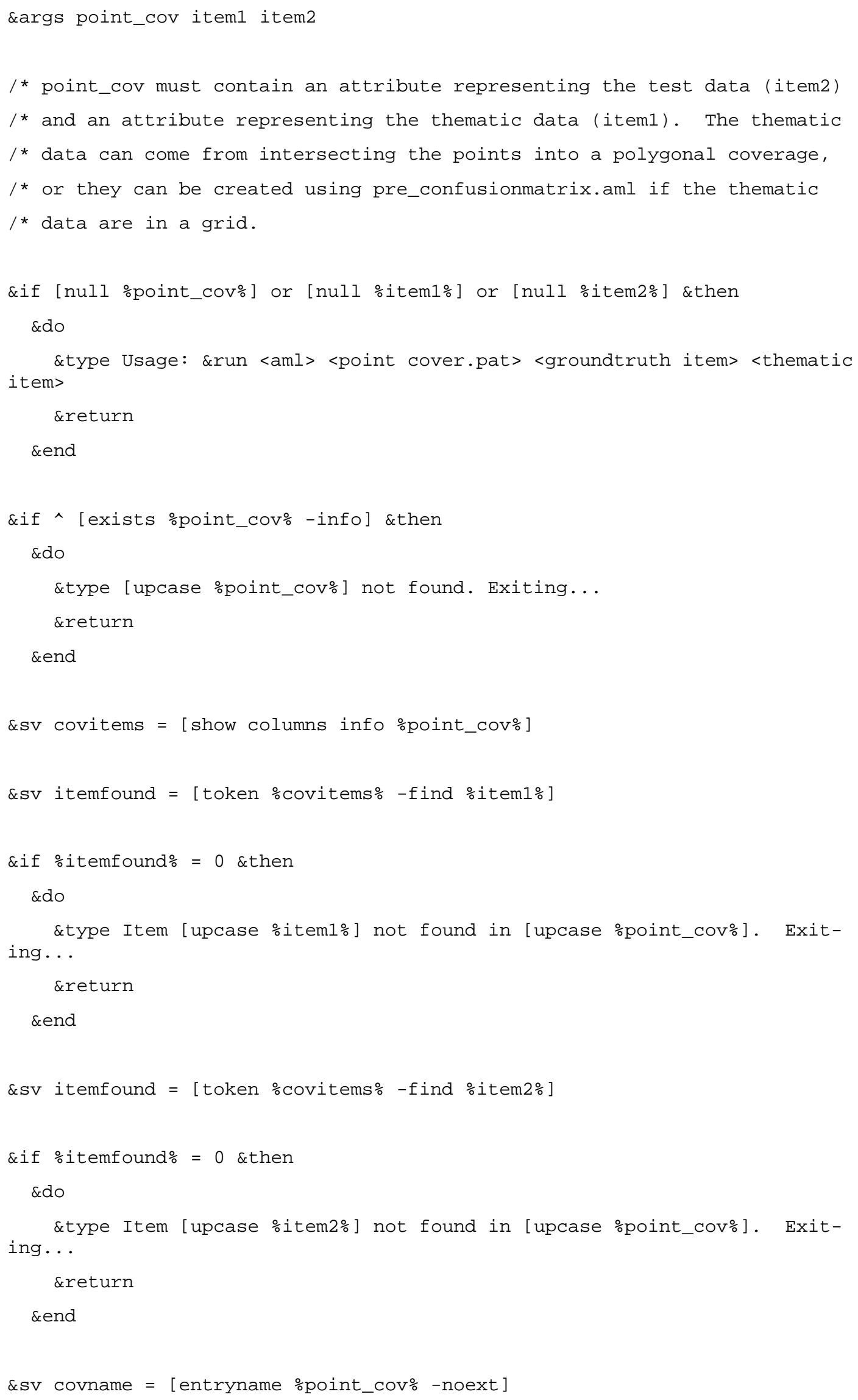




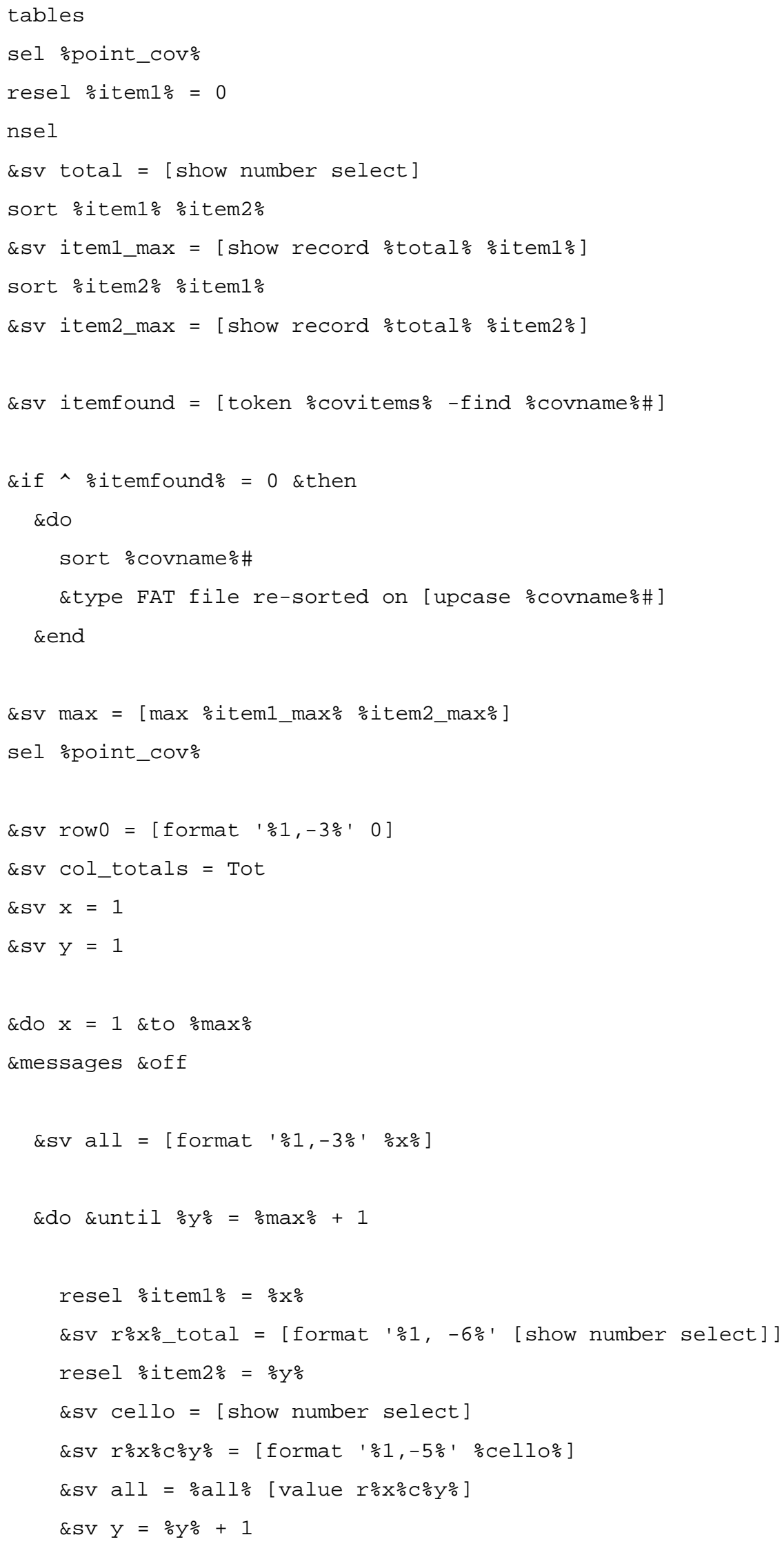


asel

\&end

\&SV row $0=$ row $0 \%$ [format ' $\% 1,-5 \%$ ' $\%$ x $]$

\&SV row $\% \circ=$ all $\%$ [value r\%x\%_total]

$\& S V x=\frac{\circ}{0} \%+1$

$\& \mathrm{SV} \mathrm{y}=1$

\&end

\&messages \&on

q

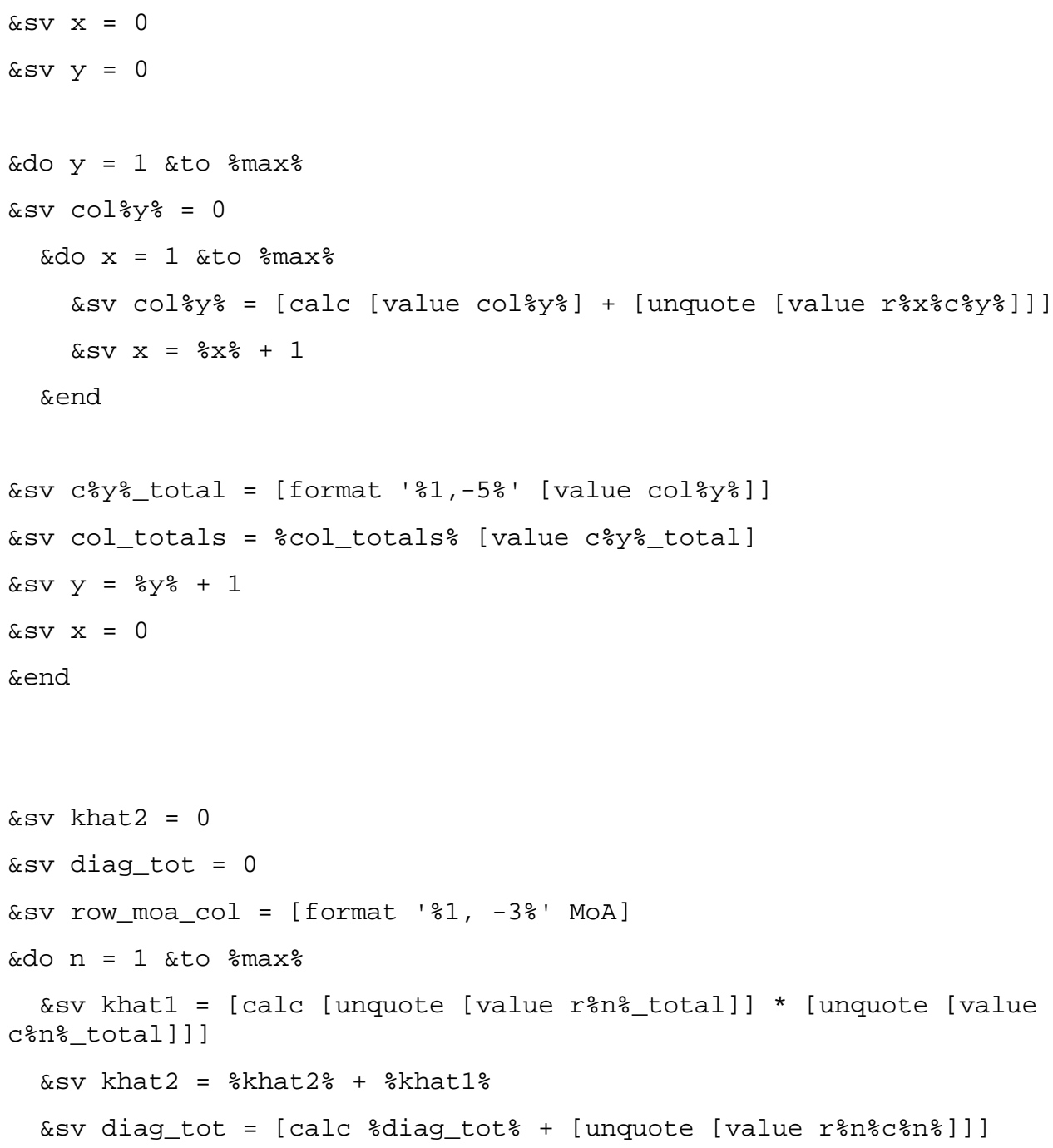




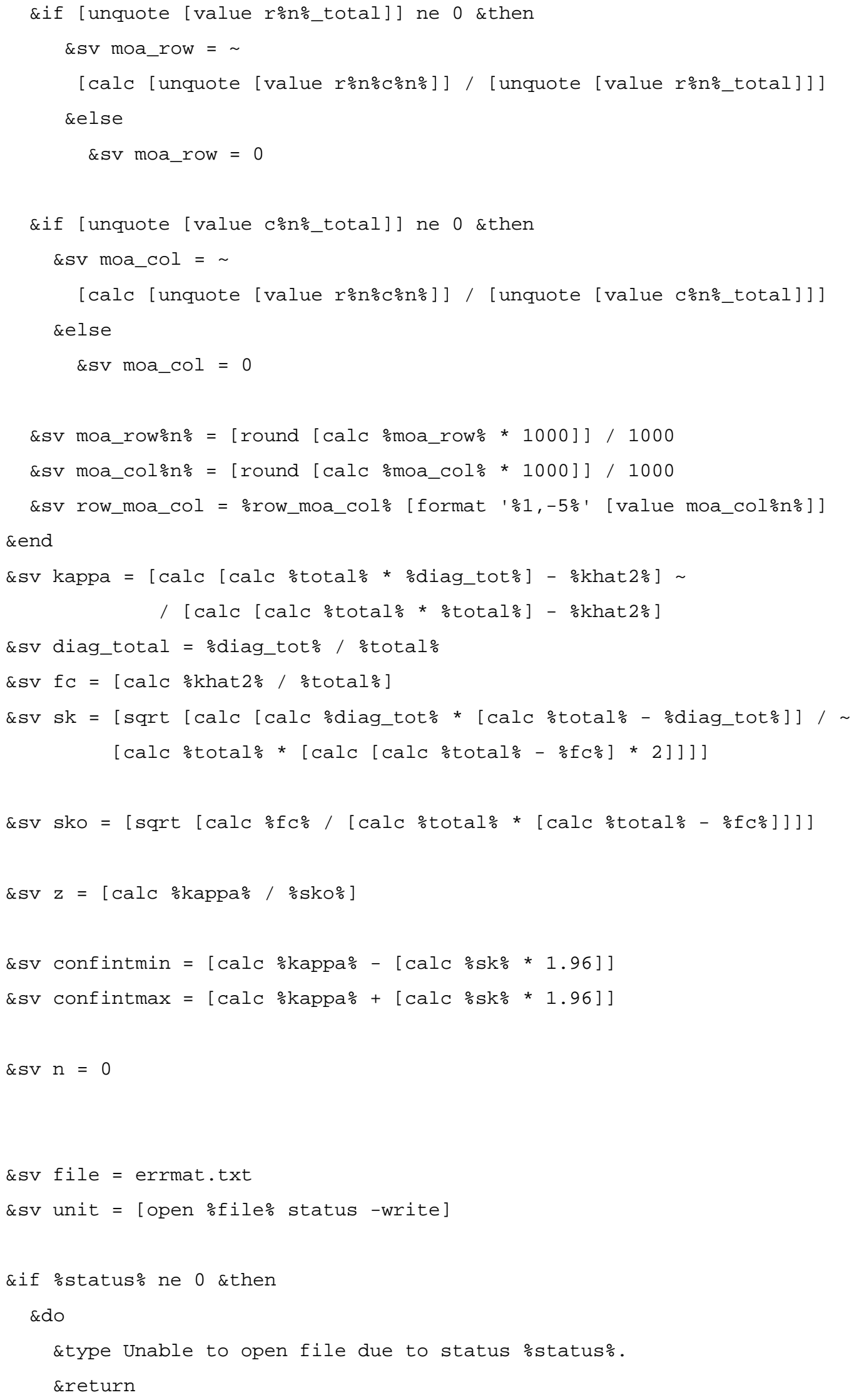




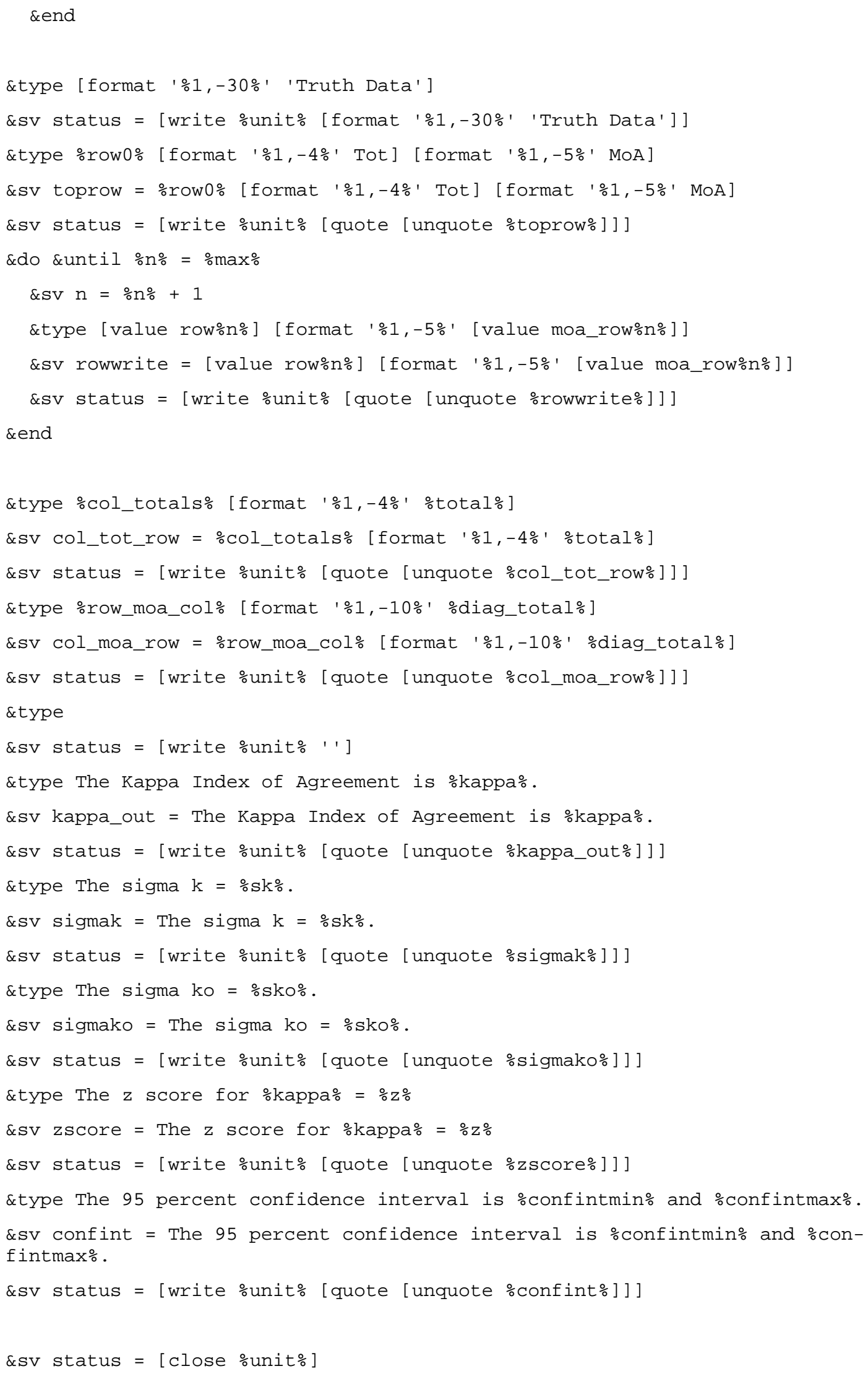


\&SV outfile $=$ \%item $1 \% \mathrm{X} \%$ item $2 \%$.txt

\&sys cp errmat.txt \%outfile\%

\&type

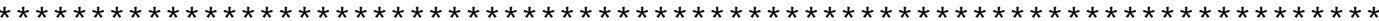

\&type Error matrix displayed has been saved to a file called $\%$ file \& \&outfile\%.

\&type

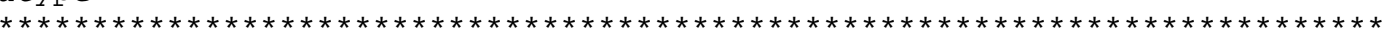

\&return 


\section{Appendix D: Field Notes}

This summary consists of miscellaneous observations made by field observers on the alliances forming the current vegetation map. Notes are based primarily on the 750 plots visited during J une 1998 through early J uly 1998, and were compiled largely by Verl Emrick. In general, the functionality of the key in the field was good. Difficulties encountered in the field were not with the mechanics of the key, but the lack of choices. There was a similar problem with the original map. In our opinion there are more alliances at Fort Benning than were identified in the map, but a more detailed vegetation analysis would be needed to identify and describe additional alliances. The following discussion consists of notes on most of the 51 classes identified in the vegetation map and TNC field key. The number in parentheses below indicates the numerical Class Number associated with the vegetation map:

(1) Pinus echinata Forest Alliance: Present on the installation, although pure stands were rarely encountered.

(2) Pinus palustris - P. elliotii Temperate Forest Alliance: This Alliance was not encountered at F ort Benning.

(3) Pinus taeda Forest Alliance: Very common, with the distinction between woodland and forest sometimes difficult.

(4) Fagus grandifolia - Quercus alba Forest Alliance: Not encountered at Fort Benning.

(6) Liquidambar styraciflua Forest Alliance: Uncommon in pure stands. Occurred most often in combination with Q. nigra and/or P. taeda. Stump sprouts of L. styraciflua dominated many of the heavily disturbed successional shrublands.

(7) Liriodendron tulipifera Forest Alliance: Rarely occurred in pure stands.

(8) Quercus alba (Q. nigra) Forest Alliance: Rarely observed. Q. nigra was an associate in early successional forests. 
(11) Quercus laevis Forest Alliance: Identified primarily as a woodland. Xeric conditions led to many mature trees being less than 5 meters tall. Pinus palustris was an occasional associate. There were many instances where all of the $\mathrm{Q}$. laevis trees had been cleared from the immediate area surrounding emergent P. palustris.

(12) Quercus shumardii - Quercus pagoda Forest Alliance: Never encountered. Occasional Ione Q. pagoda in mesic bottomlands.

(13) Quercus stellata - Q. marilandica Forest Alliance: Identified primarily as a woodland rather than forest. Common in buffer zones surrounding live fire ranges in areas that burn yearly.

(16) Liquidambar styraciflua (Liriodendron tulipifera, Acer rubrum) Temporarily Flooded F orest Alliance: A common palustrine community.

Overall many palustrine communities were combinations of two, sometimes three alliances and proved difficult to differentiate at the scale we were observing them.

(21) Nyssa aquatica - (Taxodium distichum) Semi-permanently Flooded Forest Alliance: Nyssa aquatica almost always occurred in combination with other Nyssa species. Communities with $\mathrm{N}$. aquatica were often identified as Nyssa (aquatica, biflora, ogeche) Floodplain Seasonally Flooded Forest Alliance. NoT. distichum was observed.

(22) Fagus grandifolia - Magnolia grandiflora Forest Alliance: Occurrence questionable. Possible occurrence on Shell Creek approximately $1 \mathrm{~km}$ upstream from where Sunshine Road crosses the creek. The area was less than 2 acres and located approximately 5 - 10 meters up the bluff in a cove.

The Shell creek region in general was very diverse. The terrain was very dissected and bluffs very steep. The steep biophysical gradients made the identification of alliances, at the scales necessary for mapping, problematic.

(26) Pinus taeda - (Liquidambar styraciflua, Liriodendron tulipifera) Forest Alliance: Common, although the P. taeda - L. styraciflua combination appeared to occur with greater frequency. 
(29) Pinus taeda -Liriodendron tulipifera Temporarily Flooded Forest Alliance, and

(31) Pinus taeda - Liquidambar styraciflua - Acer rubrum Saturated Forest Alliance: The two alliances were often intermixed and difficult to differentiate at the mapping scale used.

(43) Arundinaria gigantea Saturated Shrubland Alliance: None of the points we observed were placed within this alliance. However, this alliance was observed in a buffer zone for a live fire range in an area that received significant impacts from ordnance-caused wildfires.

(44) Crataegus spathulata Shrubland Alliance: The Crataegus spp. in this Alliance was misidentified in the vegetation map. The key indicated that further information was needed on the Crataegus spp. Shrubland Alliance.

Field notes indicated that this alliance occurred in exposed topographic settings where fire was a common disturbance (Pyric Disclimax ?). The Crataegus spp Shrubland Alliance would sometimes be intermixed with the (39) Quercus stel lata - Q. marilandica Woodland Alliance in areas where fire appeared to be less frequent.

Woody Associates: P. taeda, P. palustris, Q. incana, Q. Iaevis, Q. marilandica, Q. stellata, Nyssa sylvatica.

Herbaceous and Shrub Associates: Andropogon virginicus, Danthonia spicata (?), Rhus radicans, R. copallina, Eupatorium spp., Silphium spp., Rubus flagellaris (?), Pteridium aquilinum.

(47) Andropogon virginicus Herbaceous Alliance: This alliance was problematic in the sense that it was the only herbaceous class we had to choose from. The vast majority of the areas identified as the A. virginicus Herbaceous Alliance were in-fact drop zones and had a mix of herbaceous species. In many of these instances Paspalum laeve appeared to be the most common species. 


\section{CERL DISTRIBUTION}

Chief of Engineers ATTN: CEHEC-IM-LH (2)

ATTN: CEHEC-IM-LP (2)

ATTN: CECC-R

ATTN: CERD-L

ATTN: CERD-M

Defense Tech Info Center 22304

ATTN: DTIC-O (2)

Fort Benning 31905 (5)

14

$11 / 96$ 
Public reporting burden for this collection of information is estimated to average 1 hour per response, including the time for reviewing instructions, searching existing data sources, gathering and maintaining the data needed, and completing and reviewing the collection of information. Send comments regarding this burden estimate or any other aspect of this collection of Information, including suggestions for reducing this burden, to Washington Headquarters

Services, Directorate for information Operations and Reports, 1215 Jefferson Davis Highway, Suite 1204, Arlington, VA 22202-4302, and to the Office of

\begin{tabular}{|c|c|c|}
\hline 1. AGENCY USE ONLY (Leave Blank) & $\begin{array}{c}\text { 2. REPORT DATE } \\
\text { August } 1999\end{array}$ & $\begin{array}{c}\text { 3. REPORT TYPE AND DATES COVERED } \\
\text { Final }\end{array}$ \\
\hline
\end{tabular}

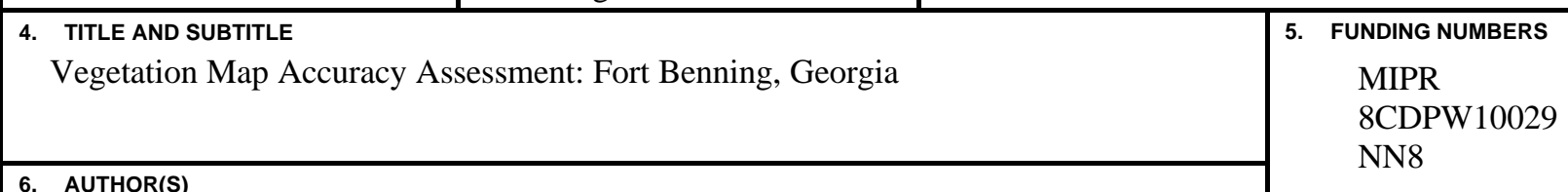

J. Watts, W.R. Whitworth, A. Hill, G.I. Wakefield, T. Davo, and L.J. O’Neil

7. PERFORMING ORGANIZATION NAME(S) AND ADDRESS(ES)

U.S. Army Construction Engineering Research Laboratory (CERL)

P.O. Box 9005

Champaign, IL 61826-9005

8. PEFORMING ORGANIZATION REPORT NUMBER

TR 99/76

10. SPONSORING / MONITORING AGENCY REPORT NUMBER

U.S. Army Infantry School

ATTN: ATSH-OTR

Bldg 2905

Fort Benning, GA 31905

9. SUPPLEMENTARY NOTES

Copies are available from the National Technical Information Service, 5385 Port Royal Road, Springfield, VA 22161

12a. DISTRIBUTION / AVAILABILITY STATEMENT

12b.DISTRIBUTION CODE

Approved for public release; distribution is unlimited.

13. ABSTRACT (Maximum 200 words)

In 1993 the U.S. Army Construction Engineering Research Laboratory (CERL) became involved in the United States Geological Survey, Division of Biological Resources/National Park Service (USGS/NPS) National Vegetation Mapping Program by serving as an interagency peer reviewer. This initial involvement led to discus-sions on vegetation mapping alternatives for military lands and a completed vegetation map for Fort Benning, GA. To validate the vegetation map and help managers realize its potential use as a natural resources and military training management tool, an accuracy assessment was conducted.

Armed with a field key to the plant communities on the Fort Benning map and a project sampling design, intensive fieldwork was conducted to collect the data required to assess the vegeta-tion map's accuracy. Field data was analyzed and an error analysis of the map was com-pleted. This report includes lessons learned and recommendations for future vegetation mapping and accuracy assessment projects.

\begin{tabular}{|c|c|c|}
\hline \multicolumn{3}{|l|}{ 14. SUBJECT TERMS } \\
\hline $\begin{array}{l}\text { Ft. Benning, GA } \\
\text { mapping } \\
\text { natural resource management }\end{array}$ & $\begin{array}{l}\text { land management } \\
\text { military training } \\
\text { vegetation }\end{array}$ & \\
\hline $\begin{array}{l}\text { 17. SECURITY CLASSIFICATION } \\
\text { OF REPORT } \\
\text { Unclassified }\end{array}$ & $\begin{array}{l}\text { 18. SECURITY CLASSIFICATION } \\
\text { OF THIS PAGE } \\
\text { Unclassified }\end{array}$ & $\begin{array}{l}\text { 19. SECURITY CLASSIFICATION } \\
\text { OF ASTRACT } \\
\text { Unclassified }\end{array}$ \\
\hline
\end{tabular}


